\title{
Czech Puppet Theatre - Tradition, Legend, and Reality: or, is Contemporary Czech Puppet Theatre an Endangered Species?
}

It is no secret that the situation in Czech puppet theatre is worrying, as many claim - judging from newspaper articles (RICHTER 2013; LEŠKOVÁ DOLENSKÁ 2014; MAKONJ 2014 and VITVAR 2012), scholarly discussions (such as the June 2014 seminar on dramaturgy in Hradec Králové that was counterpointed with informal disputes about the entry of East Bohemian puppetry on the Czech Republic's List of Intangible Cultural Heritage), or simply from behind-the-scenes debates. Apart from stating that there are no puppets in the productions of puppet theatres - which is true in publically established theatres as well as in independent companies - one of the targets of criticism in the search for the cause of the poor state of modern Czech puppet theatre is today's concept of teaching, as it is delivered by the Department of Alternative and Puppet Theatre at DAMU (the Theatre Faculty of the Academy of Performing Arts) in Prague. On the one hand, the department is the first higher education institution of its kind in the world (founded in 1952); on the other, it is constantly blamed for contemporary digressions not only from traditional techniques, but also from the achievements and legacies of the past (KYSELOVÁ 2013).

In the context of the entry of EastBohemian puppetry on the List of Intangible Cultural Heritage of the Czech Republic, the situation was reflected in an essay collection that drew attention to current problems and, to some extent, mobilised those who cared for the fate of Czech puppetry (VOJTÍŠKOVÁ 2013). The result of this effort was an official recognition of Czech puppetry as a whole as an important part of traditional folk culture, comprising many specific elements, on 19 December 2014, when 'Czech Puppetry and Folk Art Interpretation' was, as a whole, added to the List of Intangible Cultural Heritage by the Czech Ministry of Culture. Additionally there is a joint Czech and Slovak initiative towards the entry of Czechoslovak puppetry on UNESCO's Representative List of Cultural Heritage. 
Czech Puppet Theatre - Tradition, Legend, and Reality: or, is Contemporary Czech Puppet Theatre ...

For a long period of time, the state of contemporary puppet theatre has been a subject of consideration not only by theatre scholars; its rapid and somewhat chaotic - or, rather, so far unfathomable on a theoretical level - development has been commented upon not just by the experts; audiences have often felt somewhat confused as well, asking whether contemporary practice can still be seen as puppet theatre? Audiences seem incapable of combining the current trend towards the alternative with expectations of puppet theatre that they have mostly inherited from childhood experiences.

Such is the situation not only in the Czech Republic; but rather it is a more general phenomenon, as testified by a number of reflections appearing in puppetry journals, at scholarly conferences, and in publications - such as the 'Puppetry and Postdramatic Performance' conference at the University of Connecticut in April 2011 (published in POSNER et al 2014). ${ }^{1}$ In connection with these reflections on today's state of puppet theatre, a distinction is even made between puppet theatre and the so-called 'theatre of materials' (not just of objects!). The puppet may therefore be seen to have become an intermediary between the world of the living actor and many different media (JURKOWSKI 2015: 16).

It is no wonder that this situation has, quite logically, raised a number of questions questions that both experts (not just puppetry experts) and general public seek to answer. One of the first of these might be: why should changes in contemporary Czech puppetry be of public interest? The answer is simple: the phenomenon of puppetry is understood not just as part of our cultural heritage; rather, together with other phenomena, it is one of the characteristic features of Czech national identity - since even laymen are aware of the special status of puppet theatre in our history and its reputation abroad. For the purposes of this article, however, I will leave history aside - at least that part of the historical past concerned with the role of puppetry in the Czech National Revival. The widespread claim that it was only thanks to puppet theatre and the productions of travelling puppeteers that the Czech language survived - a claim that, together with other similar legends, shrouds Czech puppetry with a romanticising cloud - has long been proven wrong (MALÍK 1969). The meaning and purpose of puppet theatre in the period lay predominantly in the contact of a rural population with theatre culture as such - no matter how simplifying the view of travelling marionettists was of the famous works of European drama or literature. Let us consider typical features of this phenomenon that constituted the unique nature of Czech puppet theatre, in contrast to other European puppet cultures (such as Italian, French, and, most importantly, German) because Czech puppetry has always been important for its specific form and popularity. But is it its humour, its deployment of stage metaphor, its unique design, its puppet acting craft, or its themes that include features of our national identity? The answer is that it is no single element, but all these components combined (and their blending with other theatre genres and dispersion in them) that causes unrest around the current status of puppet theatre in our culture.

1 See also Pavel Drábek's review of the volume, i.e. The Routledge Companion to Puppetry and Material Performance, in this volume. 
When examining this fact, it is important to determine whether this distress call for the salvation of puppet theatre is a new situation or not. Is there a relationship between contemporary critique and our concept of puppet theatre? Is it fear of a loss of the exclusive status of Czech puppet theatre, which it gained significant status in the world during the course of the twentieth century (especially its last third)? What is the actual truth about Czech puppet theatre, a legendary phenomenon in a European, as well as a global context?

\section{The Czech Puppet Tradition}

The issue is not new: the fight over the form of Czech puppet theatre (stressing the 'puppet' part) has been going on for at least a century and has had several key phases that have been repeating periodically. The basis of this fight has always been the relationship to the so-often-mentioned 'Czech tradition'.

When discussing this phenomenon, it is necessary to go back in time to the period at which puppet theatre (and theatre in general) was part of a broader national cultural offensive. A significant part in this process was, of course, played by the Czech language, which was waking back to life and in which most pieces by travelling marionettists in the nineteenth century were played. Another significant factor was the effort to make accessible, in a simpler form, important works of world drama and literature, as well as popular folk tales.

A puppet, particularly a very realistic miniature of a man and, in many respects, miniatures of a 'real' theatre with mass-produced puppets and decorations that were made later, enabled an intimate home entertainment as well (often a parody of drama and opera, sometimes even a political allegory). The puppet was in a way un-punishable and its strong domestication in the Czech lands was helped by the proverbial Czech culture of do-it-yourself activities.

In the interwar period, the tendency was to make use of the potential of people's artistic talents and skills - both of renowned artists and 'folk' creativity.

In our history, an important fact was that performing puppet theatre gave people an opportunity to gather legally in educational and creative circles; doing amateur music and theatre is, after all, another feature typical of Czech national culture.

At the hands of its proponents, the aggressive popularisation of theatre forms made handy use of national sentiment, of Czech craftsmanship, and of the developing and eventually effective pedagogical influence of puppetry upon the young generation. The repertoire of accessible means that helped with this popularisation included influential cultural and theatrical puppet clubs and, since 1912, an important role was played by the magazine The Puppeteer (Loutkár).

What is tradition? And what do we understand by this term in relation to Czech puppet theatre? I shall try to find the answer in what follows, although it must be noted that 
Czech Puppet Theatre - Tradition, Legend, and Reality: or, is Contemporary Czech Puppet Theatre ...

the very concept of 'tradition' was changing throughout time (largely dependent upon the dominant ideology of any given period). In such an enquiry, some definitions may be of use:

Tradition - habits, opinions, manners, behaviour, and institutions formed in the past and preserved through generations, although they do not often have real social significance in contemporary conditions and sometimes are even an element that holds back development in the given area. A Handy Encyclopaedia (Př́ruční slovník naučný). IV. díl, Praha: Academia, 1967: 529-30)

Tradition - a body of intellectual, spiritual, cultural, and practical knowledge, skills and principles that are passed from one generation to another, by which means they are kept, deepened and spread. Tradition is, therefore, a spiritual or cultural work that has no author, is not enforced by any power or authority, although it still exists and has influence. A General Encyclopaedia in Eight Volumes (V̌̌eobecná encyklopedie v osmi svazcích), Praha: Diderot, 1999: 8: 113)

Nowadays, the term 'tradition' is understood as something that has been conducted regularly and for a long time, and passed from one generation to another. When talking about tradition in relation to puppet theatre, people usually imagine the traditional repertoire of folk puppeteers, which mostly includes variations upon Faust- or Don Juan-related stories, or popular adaptations of episodes from Czech national history, especially various forms of popular narratives that involve the switching of positions of an aristocrat and a commoner, known mainly from The Holiday in Hudlice (Posvícení v Hudlicích) (DRÁBEK 2009). As far as visual style is concerned, it is especially marionettes on wires, moving next to, and in front of, realistic backdrops and stage sets. A number of amateur puppet clubs that are about a century old fulfil these expectations; for instance, Spark (Jiskra) from Prague or the almost-a-hundred-year-old The Realm of

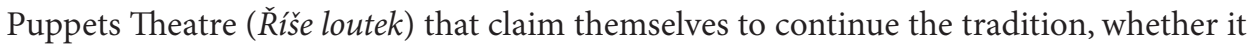
is in a sentimentally historicising or a more modern manner. Marionettes on wires have, in most cases, been replaced by marionettes on strings; but, in respect to a 'retro' fashion, some companies have returned to marionettes on wires.

The tradition of Czech puppetry, however, does not include just this repertoire and visual style, although it is marionettes that are often connected with Czech puppet tradition both home and abroad. By 'the tradition of puppetry' I mean the production of puppet theatre out of a necessity to express oneself - be it in the professional sphere or in the so-called 'leisure' space, represented by the activities of Czech amateur troupes. The most important aspect in all cases is the instrument: an object acting as a subject, a puppet, whose design and technological forms vary according to the repertoire (i.e. the dramaturgy and the director's demands). It is the puppet that is used most natu- 
rally for theatrical expression; new generations are taught how to work with it by their older colleagues, pedagogues or at seminars, workshops and through further and higher education, in the same formalised ways that musical, fine-artistic or graphical skills are passed down.

There is no doubt that the relationship to the puppet tradition is a phenomenon in the Czech Republic - some time ago, in the 2000 volume of The Puppeteer (Loutkár), a number of public figures that have a deep respect for this tradition commented upon it, namely Jaroslav Blecha, Alice Dubská, Henryk Jurkowski, Milan Knížák, Jan Novák, Petr Pavlovský, and Luděk Richter. They tried to define it and even at that time pointed out some phenomena that the Czech tradition of puppet theatre struggles with:

At the beginning of the twentieth century, the development of travelling marionette theatre terminated, and the historical baton was passed to amateurs, whose ideas of the form and purpose of puppet theatre - particularly in entertaining and educational theatre for children - started to differ significantly from those of travelling marionettists. The growing conviction that the former's theatre was a priminite anachronism was reflected in the contemptuous term 'pimprláčtina' [which can be loosely translated as 'jumping-jack theatre']. A typical feature of the new approach was the intentional disavowal from the old system of motion and voice stylisation, which was chiefly achieved by means of the amateurs' striving for a more illusionist expression, which was considered as a new ideal [...]; the acceptance or rejection of tradition is, therefore, relative. Adhering to tradition might be, at one time, a limiting factor of development; there are, however, historical phases at which tradition might be inspiring and stimulative. Nevertheless, another aspect needs to be stressed. Learning about tradition is always an important prerequisite not only for getting to know one's roots, but also gives a unique opportunity for a deeper understanding of the rules of development, which are also valid in later processes. (DUBSKÁ 2000: 13)

Such a process is not, of course, always incremental and iterative. Tradition can frequently be made new by means of its refusal, in historical moments of epistemic shift during which the old is replaced by something that presents itself as its opposite, by a new form that intentionally rejects its predecessor's form in order to be able to bring, instead of old, unproductive forms and content, new subject matter that calls for new methods. If this approach includes a system that is widely accepted, it itself slowly becomes a new tradition, which will be later subject to the same transformational destiny as its predecessor. The latter then returns in a modified form, enriched by the elements that it has absorbed, or by the views that lead it to a new, different solution which it was formerly unable to execute etc. There are, in principle, three options for our relationship with tradition: 
Czech Puppet Theatre - Tradition, Legend, and Reality: or, is Contemporary Czech Puppet Theatre ...

1) to create only on the basis of staple traditions;

2) to explore and build gradually something new that will, perhaps, in the course of time, become a new tradition or part of current traditions; and

3) to borrow eclectically and live 'outside of' all identifiable traditions.

So what is the situation of contemporary Czech puppetry? Do we still live in the sphere of the revival of the tradition of marionettes or rod puppets? Or did we a long time ago reach (and, perhaps, pass) the zenith of the tradition of the mannequin? Or do we live in the eclectic (post-)post-Modernist era outside of any traditions? Richter has observed, in an interrogation of these very ways of asking the question:

I can personally feel the strong influence of all the three or four mentioned traditions. It appears that our time is still a period of the revival of traditions and a discovering of their new possibilities - and this might be, although it would not seem so at first, thanks to the fact that there are several parallel traditions, living next to each other, that often manifest themselves in partial elements. (RICHTER 2000: 105)

The relationship to tradition, its blending and employment in contemporary puppet theatre has been a subject of discussions for several decades: it was considered by puppeteers during the 'Puppetry Renaissance' during the first third of the twentieth century, and scholars and practitioners have been returning to the topic again in past decades both in the creation of theatre art, and in theoretical reflections. Indeed, it is undoubtedly the case that such questioning forms the basis of an awareness of Czech puppetry as a phenomenon. However, in the context of discovering other possibilities for puppet theatre, there have still been many discussions about the extent to which tradition can be, in the theatre's technological, dramaturgical or interpretative elements, a limiting factor or an inspiration. The history of modern puppet theatre has, so far, persuaded audiences about the possibility of both options.

\section{The Limiting vs. the Inspiring Legend}

Perhaps the first clash with this tradition, as we understand it nowadays, took place in the early twentieth century, when fine art and theatre avant-gardes made themselves heard even in the area of puppet theatre. In the context of Czechoslovakia, we must mention the case of Josef Skupa. Although he came from the sphere of traditional puppetry, it was his experience with cabaret and visual arts that placed him in an entirely different domain to a troupe such as the Nováks - a family of puppeteers who, ultimately, left the Pilsen-based Marionette Theatre of the Holiday Resorts, aka Holiday Camp Theatre (Loutkové divadlo feriálních osad), at which Skupa and they had originally worked 


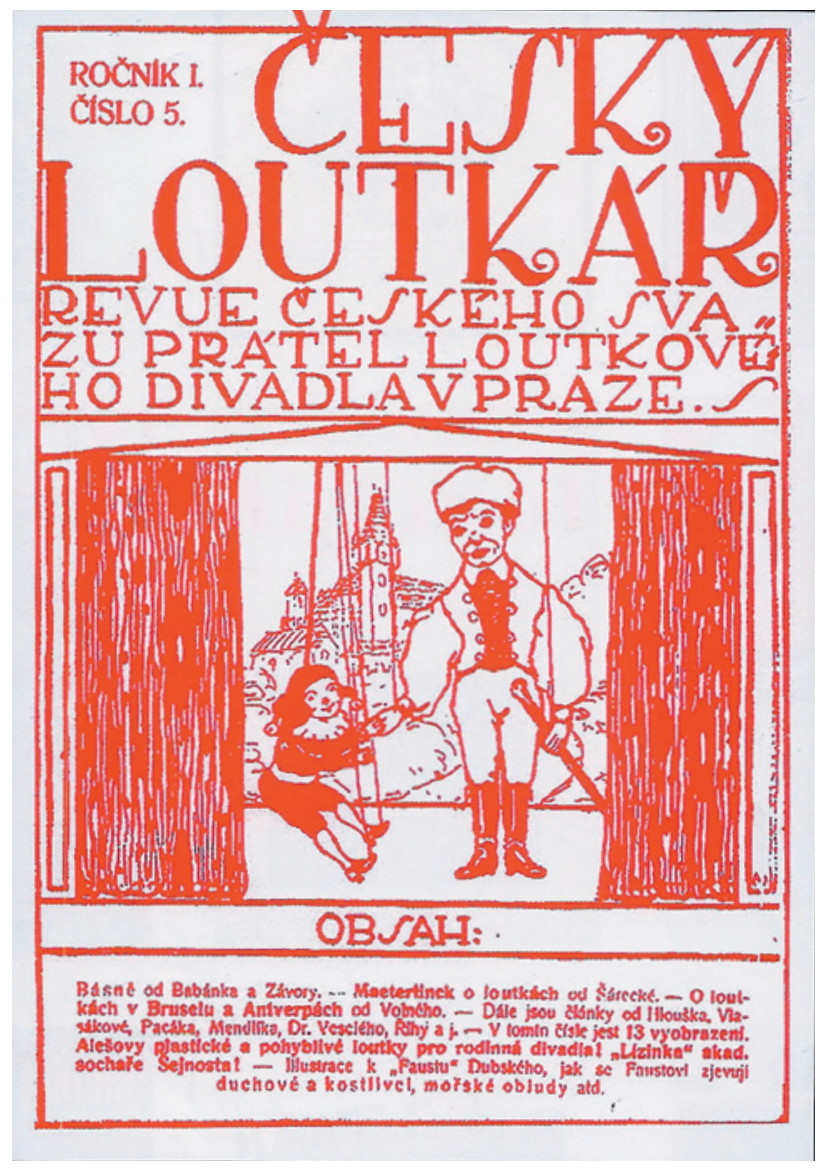

Fig. 1: Josef Váchal's title page of the revue Loutkár̆ (1912).

together. ${ }^{2}$ Skupa's artistic emancipation culminated in the foundation of Professor Skupa's Pilsen Puppet Theatre, which could, in its time, not only compete with modern European puppet scenes (particularly the German one), but ultimately gained a privileged position among them. Just like everywhere else in Europe (not only in Germany, but also in Switzerland, France and England), the fight for the modern form of puppet theatre contained a searching for new, modern design that would include not only the visual stylisation of puppets, but also the solution of the acting space and puppet design and construction (in the context of the visual art of the period, for example first abstract puppets appeared). Hand in hand with these refinements, came changes of dramaturgy: besides spectacular semi-variety shows, original modern plays appeared, such as Václav

2 For more detail, see Pavel Jirásek’s essay on Josef Skupa in this volume. 


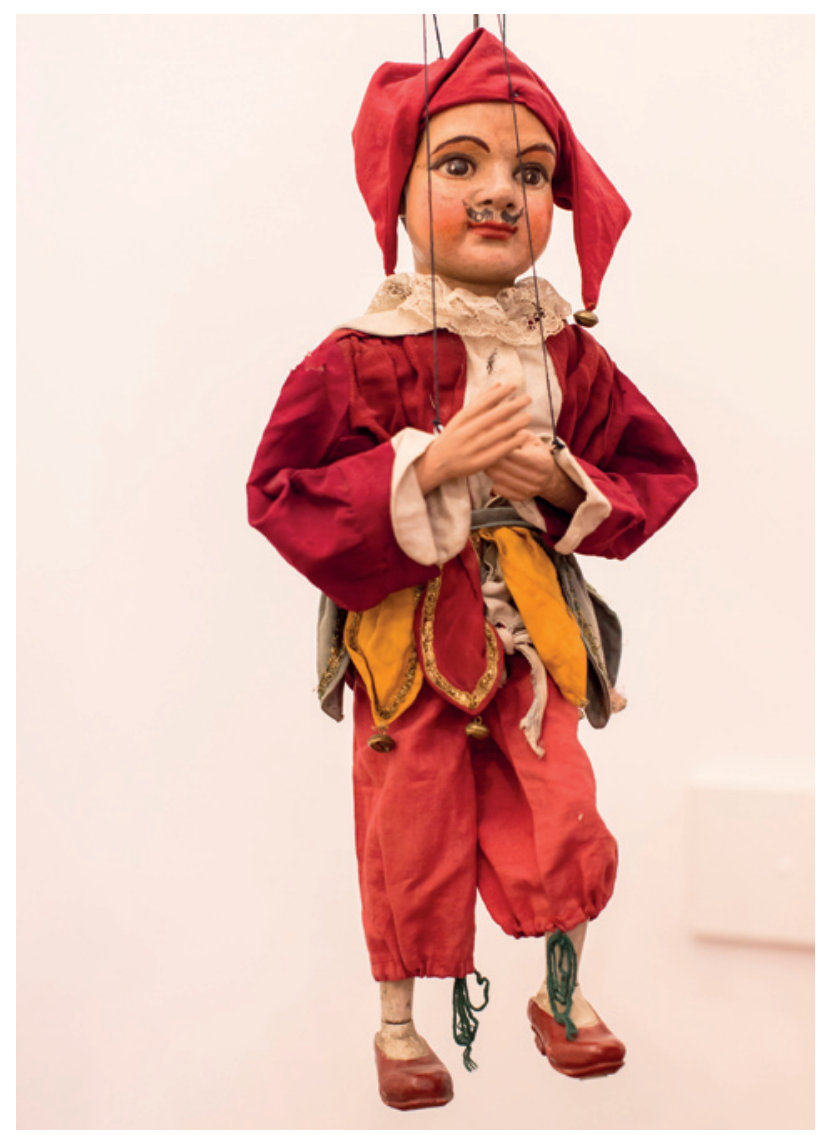

Fig. 2: Josef Adámek, Kašpárek (with a moustache). Early $20^{\text {th }}$ century. Collections of Jiři Vorel. Photograph @ Vojtěch Brtnický.

Sojka's modern variation of fairy tale motifs entitled Brocade, the Prince from a Fairy Tale (Brokát, princ $z$ pohádky), František Ptáček's Princess Oil (Princezna Nafta), which combined modern experience with folk motifs, or Jan Malík's Speckles the Ball (Miček Fliček), one of the first plays featuring a personified object as its main protagonist. ${ }^{3}$ In the face of this avant-garde advance, the once-popular miniature reductions of straight drama and operas, and the plays of travelling folk marionettists were retreating, although their practices were not yet at their very end. ${ }^{4}$

This struggle was a fight for the emancipation of a new branch of puppet theatre that continued in the offensive and presented this theatre form as distinctive, yet technically still associated with circuses and fun-fair attractions!

3 Jan Malík's Míček Flíček was published in English as Roly-Poly by Jan Malík and Milan Pavlík; retold by Jenny Dennis, illustrated by Helena Zmatlíková (Hamlyn, 1968).

4 For more detail, see Kateřina Lešková Dolenskás essay in this volume. 
Czech puppet theatre was gaining a position that was increasingly sought after; an absolutely unique and long-awaited opportunity appeared after the Second World War; and the puppeteers were well prepared for the fight. A strong offensive undertaken by puppeteers of the late 1940s and early 1950s drew from the reputation of pre-war puppet theatre, which they wanted to take up again inconspicuously (albeit carefully because of the new political situation in the country). During the Communist period (which still remains to be properly charted), the desire for an emancipation of puppet theatre and its establishment as an art form with equal status in relation to other theatre forms brought at times a hasty, at times a cruel, and at other times perhaps a logical destruction of the last vestiges of the work and existence of the historical travelling marionettists. Of course, this fight did not just comprise of the clash of Modernist efforts and a somewhat out-offashion traditionalism: hand in hand with artistic goals and ambitions went a politically inspired policy against private artists (of which class the travelling marionettists had been a part). It is unfortunate that the period of puppet reform that took place during the socalled Socialism of Eastern-bloc Czechoslovakia has been, in the course of past decades, re-evaluated several times - just like many other important and penetrative actions of that time. Once such reforms were considered as legitimate and beneficial, whereas after the Velvet Revolution (i.e. post-1990), it has been labelled as a historical mistake. However, such condemnations have always been issued without fully gathering all the facts and objective information. For instance, it would be worth examining to what extent (i.e. forced or inspiring) was the move by professional puppet theatres to 'integrate' members of travelling puppetry families into the new theatres' concepts and business practices (for instance, the Maisners into the North Bohemian Puppet Theatre and the Kopeckýs into the East Bohemian Puppet Theatre). One thing that is also interesting is the testimonies of certain members of the wider family of Kopecky, ${ }^{5}$ who describe their declining theatre business, which competed with great difficulties with modern professional and amateur puppet theatres (besides other factors, one important issue was their inability to compete with the more advanced technical equipment of the new companies).

The pressing material situation was not the sole issue. After the ban on private trade in 1945, at which time privately-run theatres were abolished; and especially after 1948, at which point within the framework of building a new network of professional puppet theatres, the so-called Theatre Law made it impossible to run a private business in this field - so that private puppeteers had either to integrate into a centrally-run enterprise (even circus productions belonged under the State Company of Circuses and Variety Theatres), or to choose another profession. Even the artistic level of established marionettists' productions was criticised (special, so-called evaluation committees were established for artists; and even solo artists had to show samples from their repertoires before approval committees, which then decided whether they and their pieces could be included in the approved programme). 
The Theatre Law (passed by the Czech National Assembly on 20 March 1948, less than a month after the Communist coup d'étât), which also defined and determined the position of cultural policy in the sphere of theatre, beat the path for centrally controlled decisions, and started the building of a network of professional puppet theatres and theatres for youth. However, although this part of the law disadvantageously changed the social status of existing puppeteers, it also brought many advantages for the future development of modern Czech puppet theatre. It was not only the network of professional puppet theatres, a project that had already started (albeit without proper state support) before the war thanks to the activities of developed amateur troupes and circles, and which came into existence due to the ideological support of the system of education of youth and infant generations.

Thanks to the newly gained position, the offensive of puppetry took place in several directions: puppeteers made use of certain cultural liberalisation after 1957 and managed to renew the activity of UNIMA (l'UNion Internationale de la MArionnette - or International Puppetry Association, founded in Prague in May 1929) within which Czech puppetry, thanks to the initiators and organisers of the Association's first post-war congress in Prague in 1957, was given an opportunity to draw attention to itself again and, thanks to re-established contacts, opened the way to the world. The activity and prestige of The Czechoslovak Puppeteer (Československý loutkár) were renewed - a magazine that continued the tradition of the pre-war The Czech Puppeteer (Českýloutkářr) and (Loutkár) that followed, as a kind of a living chronicle, changes and developments in post-war puppetry. For the newly-founded network of theatres, however, it was also vital to create a necessary school: and so, in 1952, the first higher education institution focusing on puppetry was founded, namely the Department of Puppetry at the Theatre Faculty of the Academy of Performing Arts in Prague.

The foundation stones of the discipline were therefore laid. The newly recognised theatre genre made ready use of these opportunities and, thanks to its preparedness, proved successful on all fronts within less than a decade. This unprecedented, amazing start, perhaps only comparable to the puppetry offensive shortly before the First World War, made use of all devices for popularisation, including the at-that-time infant television industry (the transmission of a production of Princess Goldilocks (Princezna Zlatovláska) by the Central Puppet Theatre in Prague in 1952 into a television studio was the first such attempt in Czechoslovakia)!

\section{The 'New Tradition' and the Revolt against It}

Under the new conditions, marked by the building of a network of professional puppet theatre, the Skupa Theatre became (unwillingly) a 'traditional' institution (it used - just as it does today - marionettes, and its dramaturgy was based on the comic-grotesque 


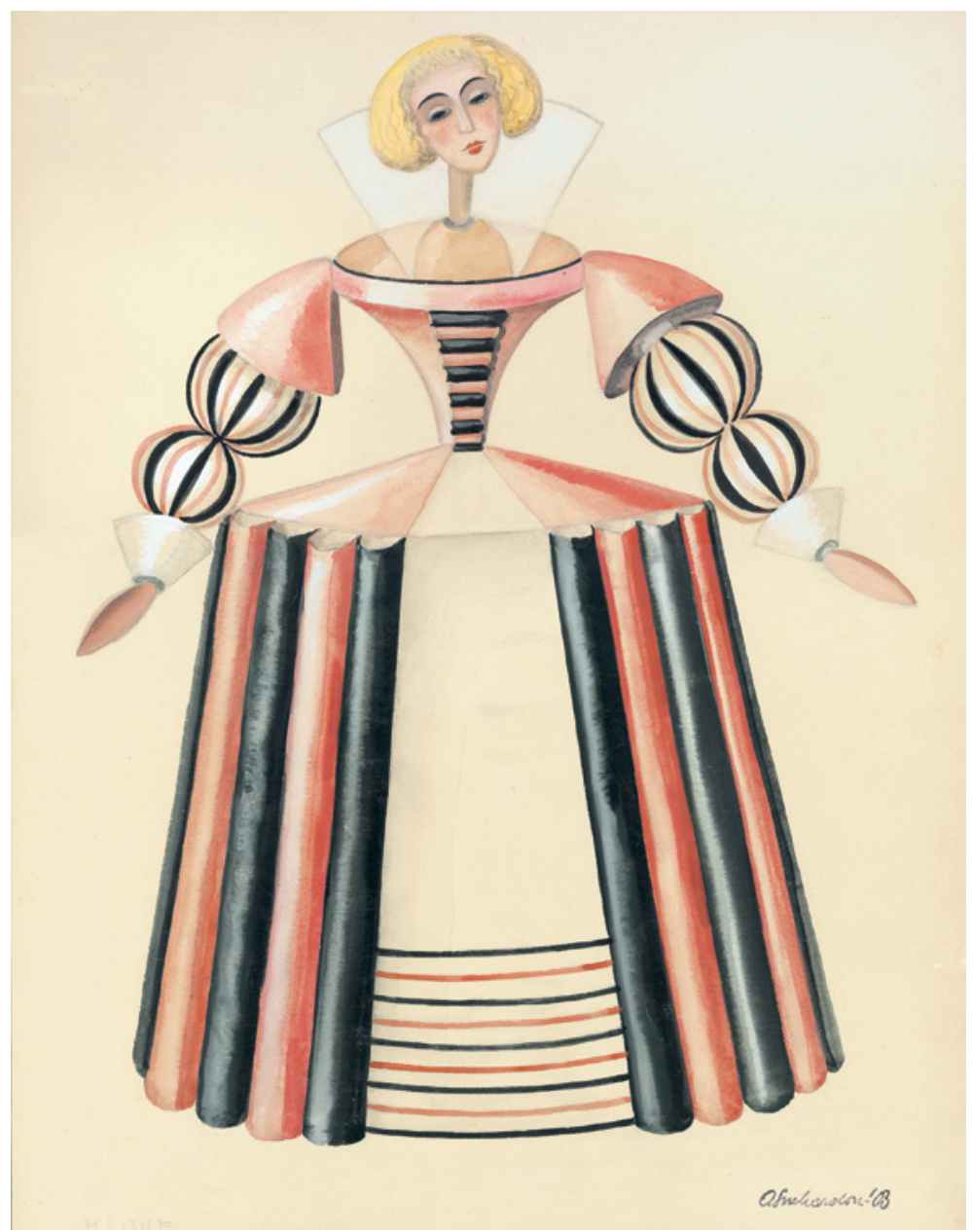

Fig. 3: Anna Suchardová-Brichovás design for Olivia for a production of Shakespeare's Twelfth Night (Večer tříkrálový). The Říše loutek Theatre, Prague 1925.

tone of the previous repertoire and, of course, on the popularity of the figures of Spejbl and Hurvínek), whereas the Central Puppet Theatre was seen to be the bearer of 'progressive' techniques. The fight of these two Prague theatres, both struggling for spectators' favour and popularity (the Skupa Theatre was able to preserve audience loyalty without abandoning its own style), mirrored many cultural-political fights of the period, and would deserve an independent study.

The Moscow wayang golek puppet school enchanted, in December of the fatal year of 1948, Czech puppeteers with its pomp (yes, even pomp played its role), its brilliant puppet technique and its illusiveness, and caused something of a splash in the Czech 
Czech Puppet Theatre - Tradition, Legend, and Reality: or, is Contemporary Czech Puppet Theatre ...

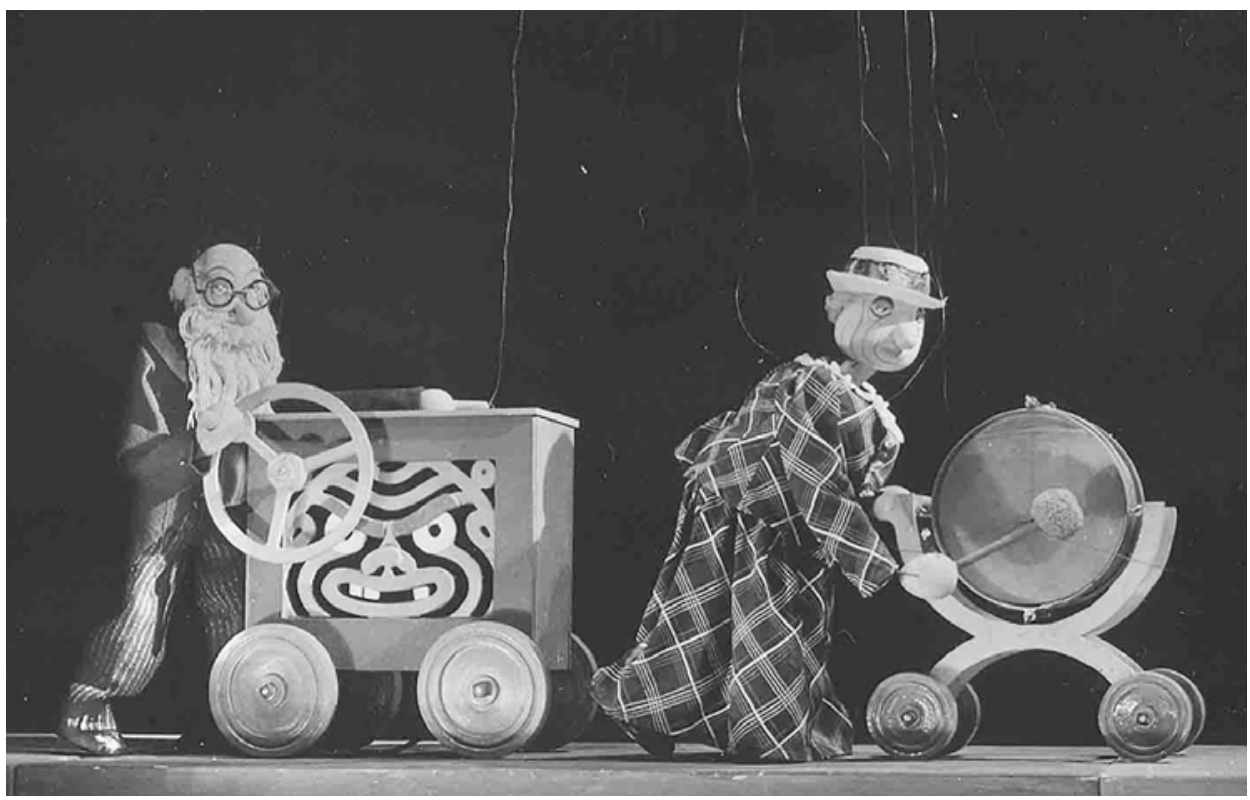

Fig. 4: A scene from Jan Malík's production of his play Speckles the Ball (Míček Flíček). Scenography by Jan Malík. Umělecká výchova Theatre, Prague 1926. Photograph @ archive of Nina Malíková.

lands. Czech puppeteers made skilful use of the series of productions of the Moscow Central Puppet Theatre, lead by Sergei Obraztsov, in Prague (13 December 1948 - 31 January 1949) in order to build definitely a vast network of professional puppet theatres (as always, in the name of the form's beneficial effects upon young spectators), but also to strengthen its position and finish the building of a second permanent (central) professional puppet theatre in Prague with what was, by the standards of the day, an extraordinarily large ensemble and a sophisticated range of technical equipment. With respect to what has been said, it was only seemingly surprising about this scene - whose establishment had been called for even before the war (the headquarters of Skupa's theatre's was in Pilsen back then and moved to Prague only after 1945) - that, apart from 'traditional' marionettes, which were the pride of major Prague amateur puppet scenes, in The Puppet Theatre of Artistic Education (Loutkové divadlo umělecké výchovy) as well as in the Sokol Association in Prague-Libeñ (from which most of the members of the Central Puppet Theatre were recruited) that puppets controlled from below, the socalled 'wayang puppets', appeared as well, after the fashion of the successful tour of the Moscow Puppet Theatre. The producers of this exemplary scene, however, soon realised that they could not abandon their origins. A Czech 'wayang school' was established (it would be interesting to undertake research into the extent that and the means by which distinct manifestations in Prague, Brno and Ostrava differed), which could be, in retrospect, called 'traditional' in that it strove for the unity of Czech design, the preservation 
of Czech technological skills, and Czech dramaturgical uniqueness. The creators, who were brought to the Czech puppet scene mostly by the dramaturgy of the Central Puppet Theatre (in this respect, a crucial role was played by Erik Kolár), created the basis of a lyrical-comic repertoire, to which other Czech amateur and professional theatres resorted during the decades that followed. At a time when the wayang puppets fell out of fashion, these new plays gave puppet theatre a novel form, and became eventually the most valuable pieces of the Czech puppet repertoire and production history. The most telling example of this is Josef Kainar's Goldilocks (Zlatovláska); its productions - such as those by directors Jan Malík (1952), Josef Kaláb (1953), Karel Brožek (1977) and Josef Krofta $(1981,2008)$ - can be seen as documentary case - studies of the various stages of the history of Czech puppet theatre.

The brief sojourn of wayang puppets in the Czech lands has now been largely forgotten (very few people can actually 'play' these puppets nowadays); but the thinking of the work with a puppet that appeared in this period (see for example OBRAZCOV 1947 and OBRAZCOV 1955 for Obraztsov's works that were on a kind of compulsory reading list of every puppeteer at the time), has remained central and is often revived by those who, on the one hand, do not want to return to the practices of travelling marionettists and their repertoire, but, at on the other, want to draw from this period of the cult of the puppet and its stage hegemony.

The predominant period of wayang puppets lasted for only a decade; however, it influenced all Czech professional puppet theatres and even touched, albeit not very significantly and in a rather unfortunate way, the Spejbl and Hurvínek Theatre, who produced the one-act play Iegorek's Locomotive (Jegorkova lokomotiva) by the Soviet author Nikolai Kharkov in November 1952. The academic nature of the wayang style, represented chiefly by productions of the Central Puppet Theatre, its illusiveness, which tried to - against the nature of puppet theatre - imitate perfectly the theatre of 'living actors', and its enchantment with puppets controlled from below, with their broad and sweeping gestures quickly started to exhaust itself. The first blow that signalled that something was happening was the Festival and Seminar of the Central Puppet Theatre in Karlovy Vary on 21-28 August 1960 at which, despite a clash of generations, the contemporary model was openly criticised for the first time. In the discussion, the young generation of the Spejbl and Hurvínek Theatre (namely Jan Dvořák and Miloš Kirschner) expressed their very critical opinions - both of them would later play key roles in the development of Czech puppet theatre.

Another place for an offensive against this style of theatre was, paradoxically, the school environment. It was the Department of Puppet Theatre at the Academy of Performing Arts in Prague that the creators of modern puppet theatre founded for their theatre network and in which, as pedagogues, they systematically exercised their style. Besides wayang puppets, hand puppets and, sporadically, marionettes were also gradually appearing on and off the school scene; and it was here that the first voices of students 
of the Academy of Performing Arts were heard. Significantly, they claimed that training in puppet skills was not enough for them, and they demanded broader insight on the part of the pedagogues; they called for a theory of puppet theatre, which would still be up-to-date in the context of current thinking about theatre, and they were eager to broaden outwards from their National perspective, in order to learn more about puppet theatre throughout the world. This is the place in which we can feel the first signals of today's progress (as well as sensing lamentations over forsaken tradition). The considerations about the puppet that sporadically started appearing provoked young puppeteers to see various possibilities in their subject.

The fact that not only students were unhappy about the situation, and that the first critical voices reflecting their opinions appeared in printed media as well can be demonstrated, for instance, in the polemics about the evaluation of certain school productions in The Czechoslovak Puppeteer (Československý loutkár). The concerns of students were also noted by Radovan Krátký in the periodical Theatre News (Divadelní noviny), which publication's articles were concomitantly followed by polemics by the pedagogues, again in The Czechoslovak Puppeteer (Československý loutkár). The whole atmosphere of this time has been described, including a thorough bibliography of published and unpublished materials, by Pavel Vašíček, in his series of articles devoted to the first years of the Department of Puppet Theatre (VAŠÍČEK 2014b and 2014c). Here he observes:

People, for instance, accuse university students of puppetry with the following: that all they care about is theory; that they do not understand theory at all; that they elevate practice above theory; that they are filthy in practice; that they are good for nothing. The less scathing individuals recommend that the university of puppetry be chiefly based on practice. Others call for [access to] theoretical literature that does not exist. Others still note that graduates of the Puppetry Department open their mouths when reading the dialogue sheet, but not in order to speak aloud but rather because they gape, not knowing how to handle the spoken part. Some want the young puppeteers to work through experiment, while others maintain that the young need first and foremost [to master] the rudiments that they would gain chiefly in theatres and then elaborate upon them at university. And others are happy about the graduates of the Department. [...] I believe that we have to be extremely careful to state who should do their laundry first. School is not just students, but teachers as well (both of high and not-so-high quality), the curriculum (appropriate and less appropriate), and extra-curricular influences etc. [...] The Department of Puppet Theatre [at DAMU] is an institution we can be proud of in the context of the world. Understandably, it has no long tradition, and the [lack of] erudition in the pedagogues of puppetry was often compensated with enthusiasm. One could only envy the enthusiasm and devotion of certain puppeteers. However, these are never satisfactory just by themselves. (KRÁTKÝ 1962: 21-2) 


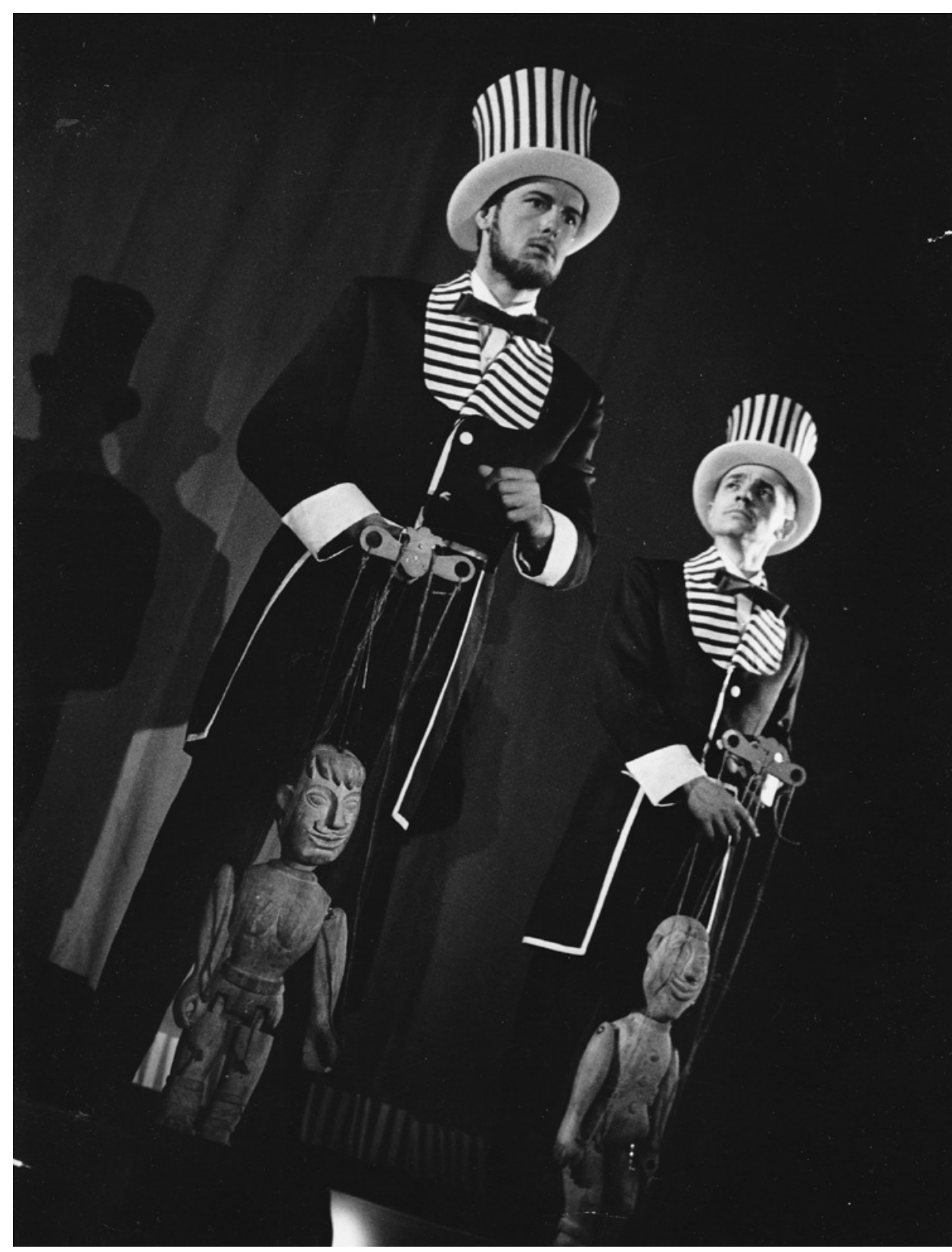

Fig. 5: Jaroslav Dudek's production of Hana and Josef Lamka's Not Worth It (To nemá cenu). Černé divadlo Hany a Josefa Lamkových (H. and J. Lamka’s Black Theatre), Prague 1963. Scenography by Josef Lamka. 
Czech Puppet Theatre - Tradition, Legend, and Reality: or, is Contemporary Czech Puppet Theatre ...

2015

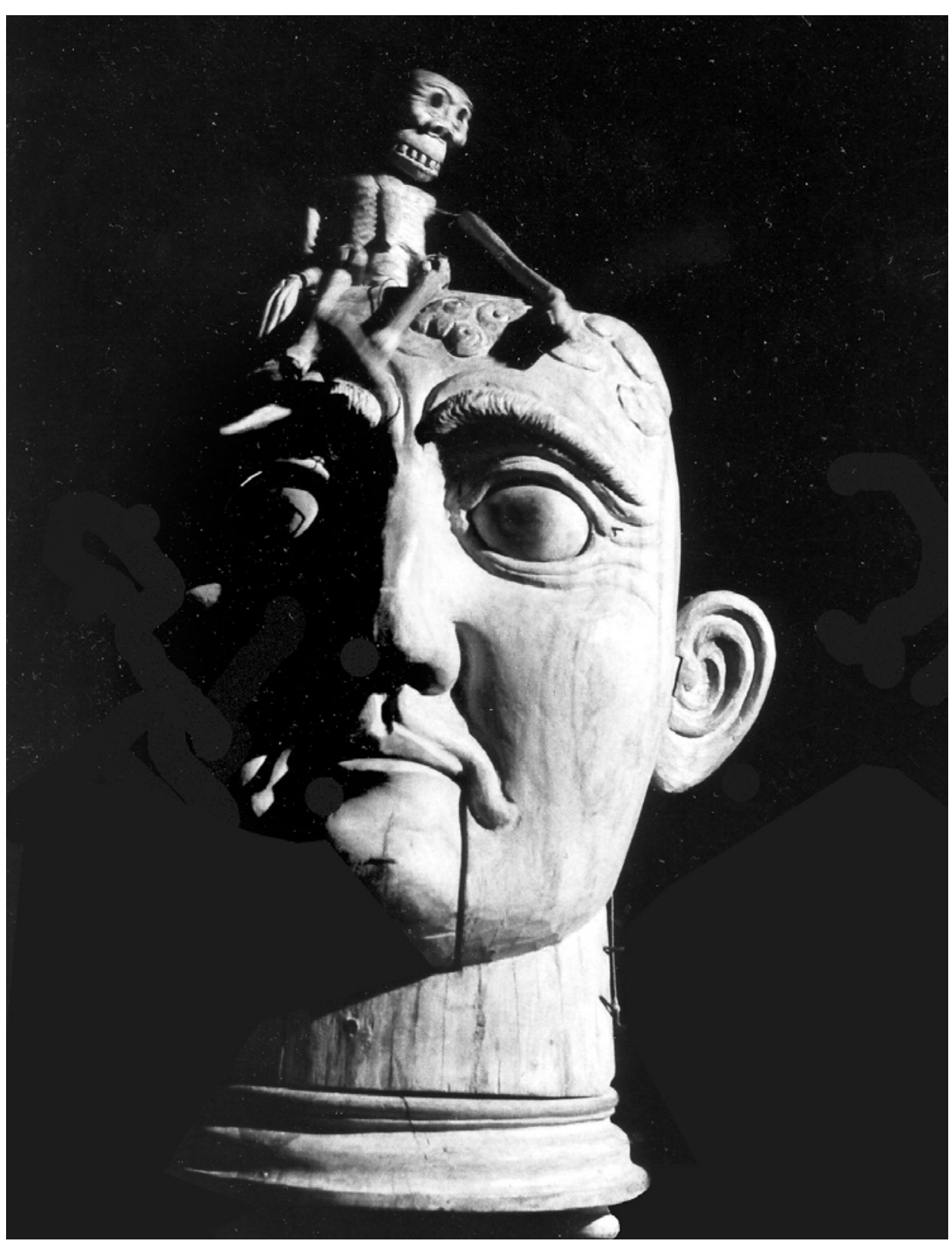

Fig. 6: František Vítek’s puppets for Věra Říčařovás production

of a Piškanderdulá. Scenography by František Vítek. Hradec Králové, 1977.

Photograph (c) Jan Merta. 
It should additionally be noted that at an artistic school, it is NOT only knowledge that matters, but, in cases of main subjects, it is also - perhaps predominantly - professional credit (which, however, is not always accompanied by pedagogical talent - Josef Skupa might be an example). Thus the theatre that might have been seen, for instance, at the Gorký Square in Prague (in the Central Puppet Theatre), probably was not the desired goal and inspiration for the majority of students. Of course, even an abnormal holding of several positions at the same time (albeit non-lucrative) was (and still is) a problem. Krátký therefore calls for a division of forces, jobs and functions to earn some time and energy for academic activity and self-development; and, most of all, for creative work with students. The common feature of most defects is, according to Krátký, a surviving culture of amateurism (for more information, see VAŠÍČEK 2014). Krátký considers the state, in which:

several Proteuses of puppetry continue, according to the situation, enthusiastically transforming into professors, managers, researchers, actors, representatives, lightning technicians, critics, authors, theoreticians, directors, set designers and musicians [but such multitaking is unsustainable, so that] what is tragic (for puppet theatre), is the fact that very few practitioners admit that they cannot be best at all these things. (KRÁTKÝ 1962: 22)

In the liberated atmosphere of the 1960s, however, a searching commenced for 'quotidian beauty', which became one of the dramaturgical pillars of the repertoire of the theatres of 'small forms'. Finding the poetry of everyday objects became a fertile ground for a theatre without complex texts, a chiefly visual theatre that sought to be informative, poetical, non-bombastic, which found its strongest place in the so-called 'Black Light Theatre'. As part of this tradition, a wave of magic, floating objects and their apparently independent, animated lives offered subtle metaphors in relation to the life of humans. Such shows flooded not only small stages (and amateur companies), but black masks and velvet costumes became, for a considerable period of time, almost compulsory articles in the actors' dressing rooms of most Czech professional puppet theatres. However, just as every kind of magic loses its beauty, so did this one - whose dramaturgy did not really develop in Czechoslovakia (because the key members of the black theatre group were, after the Soviet invasion of 1968, 'sentenced' to live abroad and could not contribute to the development of the genre in their homeland; see LAMKOVÁ 2009:12-7, 62-3). So, although Black Light Theatre remained just one of the possibilities of puppet theatre, the initial enchantment was over and, right up to the present, it has chiefly traded on its former reputation. The same is true of a majority of variety shows, which were very close to Black Light Theatre's productions and practices, and have now simply become a commercially successful segment of Prague's tourist industry; so that they are no longer considered as part of contemporary Czech puppet theatre. Such fads and phases went as easy as they had come (just as wayang puppets did before them) and today, we would 
Czech Puppet Theatre - Tradition, Legend, and Reality: or, is Contemporary Czech Puppet Theatre ...

not find them on Czech puppet stages (although their variants can perhaps be detected in the best non-variety-show-like entertainments, and also in a Surreal, existential sense they can again be seen to rule European stages, chiefly through the work of the French Philippe Genty and his students, and also to keep enchanting even southern-European productions).

Whatever the reasons were for the weakening of what had been up to that point a continuous offensive, it is certain that, by the late 1960s, Czech puppet theatre began to stagnate. Was this torpor due to forced separation from the rest of the world? Or did the emphasis on ever-transforming techniques exhaust itself? This is hard to say. The 1960s, however, present a paradox: the decade was the strongest in modern Czechoslovak theatre; and it was also the decade in which puppet theatre ceased to play an important role. One of the first to point out the stagnation of Czechoslovak puppetry was the renowned critic J. A. Novotný, with respect to a comparison of Czech and world puppetry at the festival in Bucharest (1 May to 1 June 1958). He observed:

'Czechoslovakia has lost its dominant position in the sphere of international puppetry' reads the 16 July, 1958 issue of Theatre News (Divadelní noviny). That's an observation hardly to argue with. [...] And then, let us ask ourselves: is our situation really that bad? If we are any good, we will struggle for quality at any cost. Unless we stepped aside ourselves and retreated from the scene, we cannot just accept this statement. The title of 'superpower', which, quite frankly, has been for some time a rather suffered historicising gloriole, is not worth [crying over], not even one tear. [...] How do we want to sift and collect values, if they are just the same old stuff, derivations, and copies? [...] If we do not liberate ourselves from the circle in which we only hear the train of our miseries over and over again, we are sentenced to a fight for endurance, not victory! Change trains, Czechoslovak puppeteers! It is high time to change! (NOVOTNÝ 1958: 245)

The fully critical statement of the then-current state of things appeared around Skupa's Pilsen - a national festival that, throughout its existence (since 1967), has became a kind of display of the best of Czech puppetry and the feedback from it, in the form of critical essays and a charting of its state.

A shift in puppet theatre could not be stopped: living actors entered the puppet stage, and it was not just as it had been in cases such as Sergei Obraztsov's and Sergei Preobrazhensky's Ivan the Great (Bolshoi Ivan, of 1937) which had been taken over from the repertoire of Obraztsov's Moscow theatre, in which the living actor was just a metaphor, a personification of the Russian people. Now the actor appeared in new and multi-sense relationships with puppets in a common playing space that removed a number of limitations that set designers had previously faced. With unabashed this entrance of the human form to the puppet stage, a sound of alarm was set off. People asked: 'Is this still puppet 
Czech Puppet Theatre - Tradition, Legend, and Reality: or, is Contemporary Czech Puppet Theatre ...
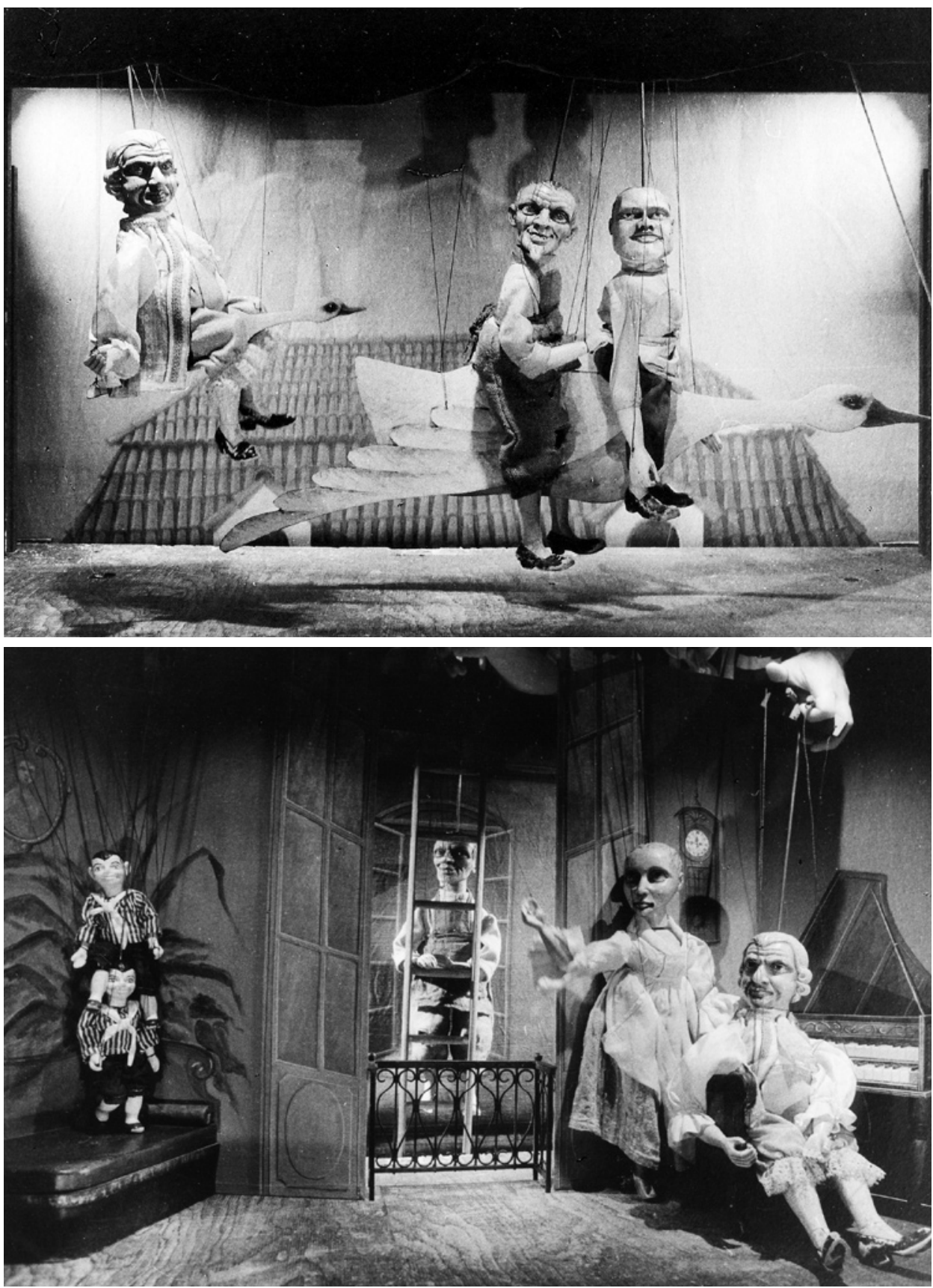

Fig. 7a+b: A scene from Petr Forman's production of Baroque Opera (Barokni opera), based on Karel Loos's The Czech Opera of the Chimney, ca.1770 (Opera bohemica de camino). Scenography by Jan Marek. Divadlo bratř́ Formanů, Prague 1992. Photograph @ Josef Ptáček. 
theatre?' Questions like this one were stirred by the appearance of directors who started to work with the puppet in a somewhat different way and necessitated a new view of the theory of contemporary puppet theatre and its form in the Czech environment (here I principally mean Karel Brožek, Jan Schmid, or, later, Josef Krofta). Seminal material on this topic was provided by Jan Císař, who, in his series of articles for The Czechoslovak Puppeteer (Československý loutkář) magazine, thoroughly addressed and analysed what puppet practitioners and their audiences had been at a loss about (CÍSAŘ 1978). In his study, Císař discusses the status of the living actor on the stage; and tries to determine the role of the puppet and work with it in analyses of productions of the time:

In this production [Kainar's Goldilocks], Brožek has absolutely persuasively shown that [theatrical] direction in Czech puppet theatre has adopted a number of elements that can enrich and strengthen the voice of puppet theatre and that it can employ these elements in a kind of polyphony. And that, after all, this reflects upon what has been happening around puppet theatre, because 'specific artistic structures are nothing rigid, but developing; it only needs to be remarked that various kinds of art constantly influence one another, by which they modify their structural forms. This is Brožek's strength. And it is also one of the greatest impulses of contemporary [theatrical] direction in Czech puppet theatre. (CÍSA ̌r 1978: 78)

Josef Krofta and the DRAK theatre made use of the newly available possibilities of stage direction and scenography and based their unique style on this connection; in the last three decades of the twentieth century, the style of DRAK was literally influencing the form of puppet theatre not just in continental Europe, but even overseas. It is, however, interesting to note that the 'new' style - presented chiefly by means of distinctive dramaturgy (whether the dramaturg was Jan Dvořák or, later, Miloslav Klíma) of this perhaps best-known of modern Czech puppet theatres - started its theatre offensive somewhat earlier; and it was through a return to inspirational sources from the puppet tradition that the 'rebellious', then youngest puppet scene of ours (The East Bohemian Puppet Theatre, later DRAK theatre) stood victoriously; and through concrete deeds took their stand against the fading era of wayang puppets. This articulation of what was good and useful in the indigenous Czech tradition came through repertoire pieces such as The Holiday of Hudlice (Posvícení v Hudlicích) 1966); A Comedy of Františka and Honzíček (Komedie o Františce a Honzičkovi, 1968); Dr John Faustus (Johanes doctor Faust, 1971); The Highwaymen at Chlum (Loupežníci na Chlumu), or through the use of particular marionettes; the great artistic contributors were mainly František Vítek, later Pavel Kalfus and Petr Matásek. 


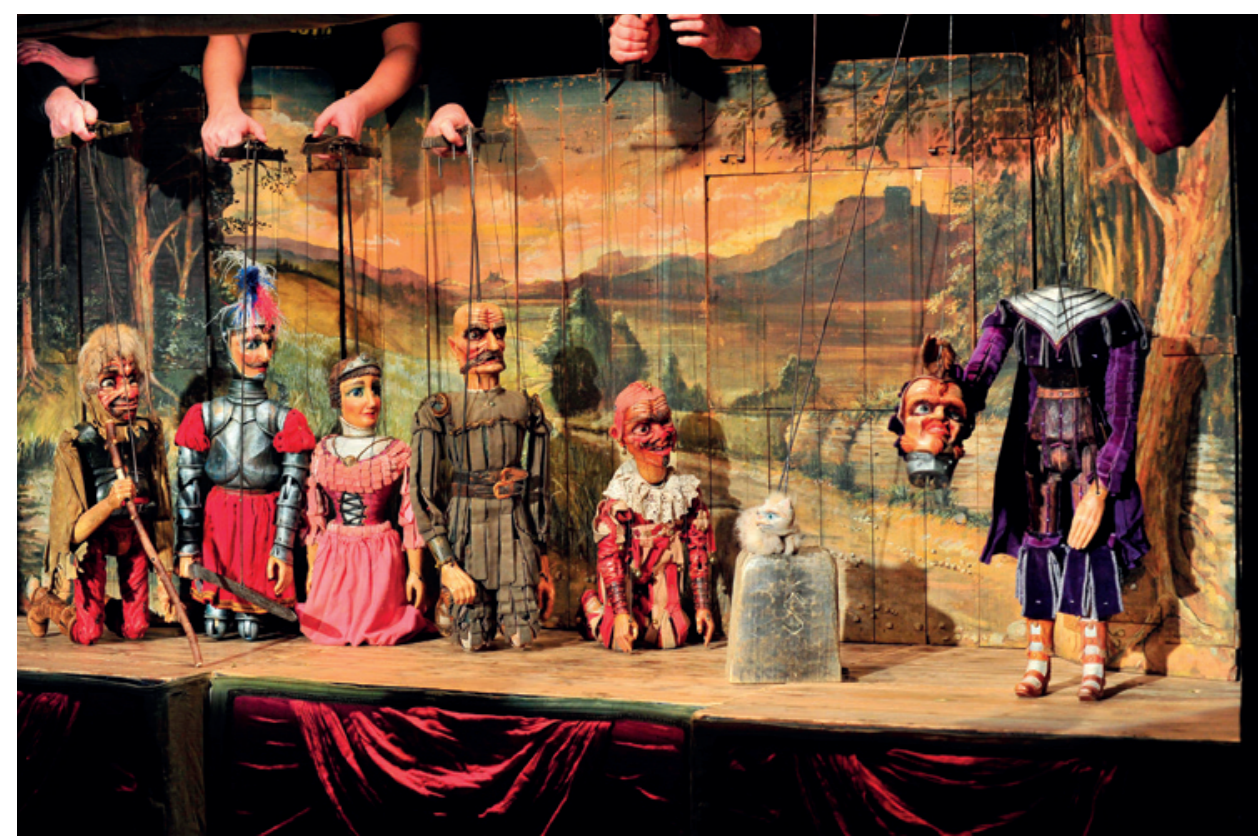

Fig. 8: Tomáš Dvořák’s production of Iva Peřinovás The Headless Knight (Bezhlavý rytír).

Scenography by Ivan Nesveda. The Naïve Theatre Liberec, 1993. Photograph @ Josef Ptáček.

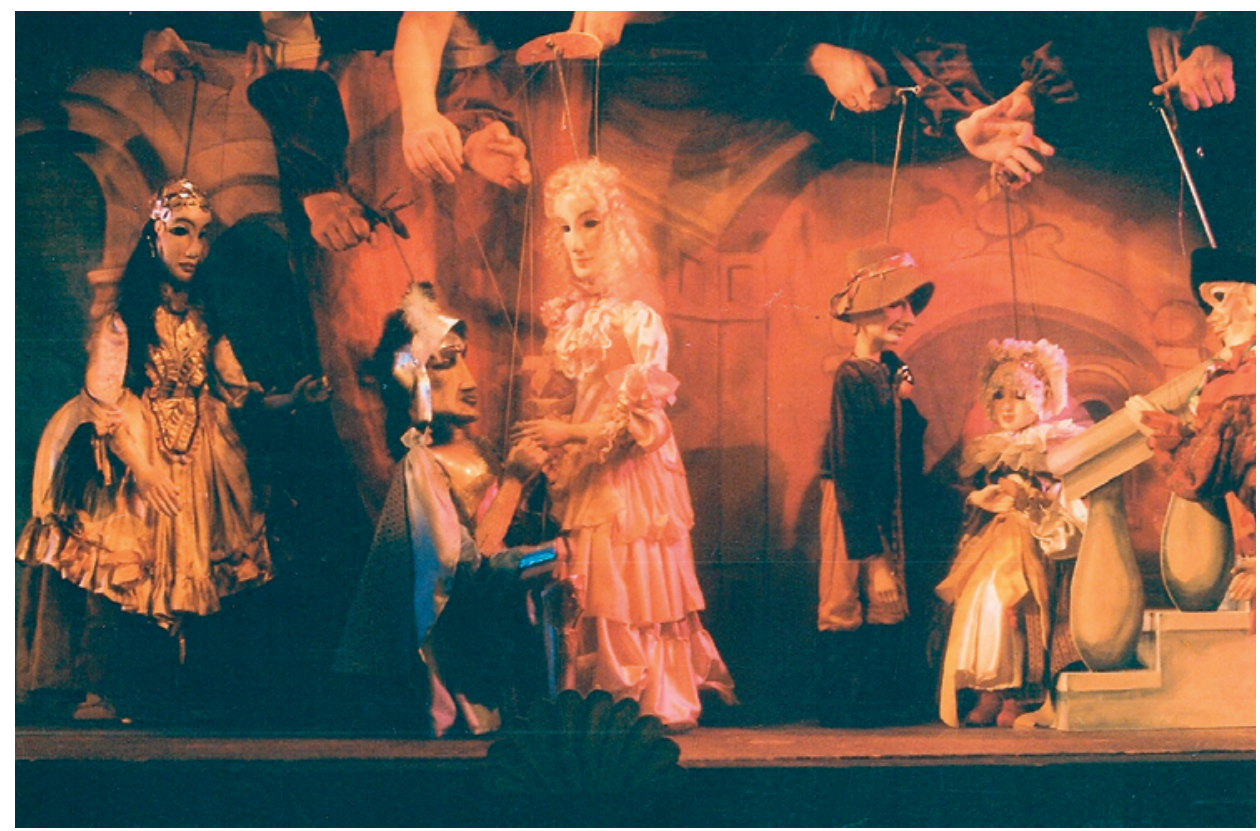

Fig. 9: Karel Brožek’s production of Mozart’s Don Giovanni. Scenography by Hana Cigánová. The National Theatre of Marionettes (Národní divadlo marionet), Prague 1991. Photograph @ Josef Ptáček. 
Nina Malíková

Czech Puppet Theatre - Tradition, Legend, and Reality: or, is Contemporary Czech Puppet Theatre ...
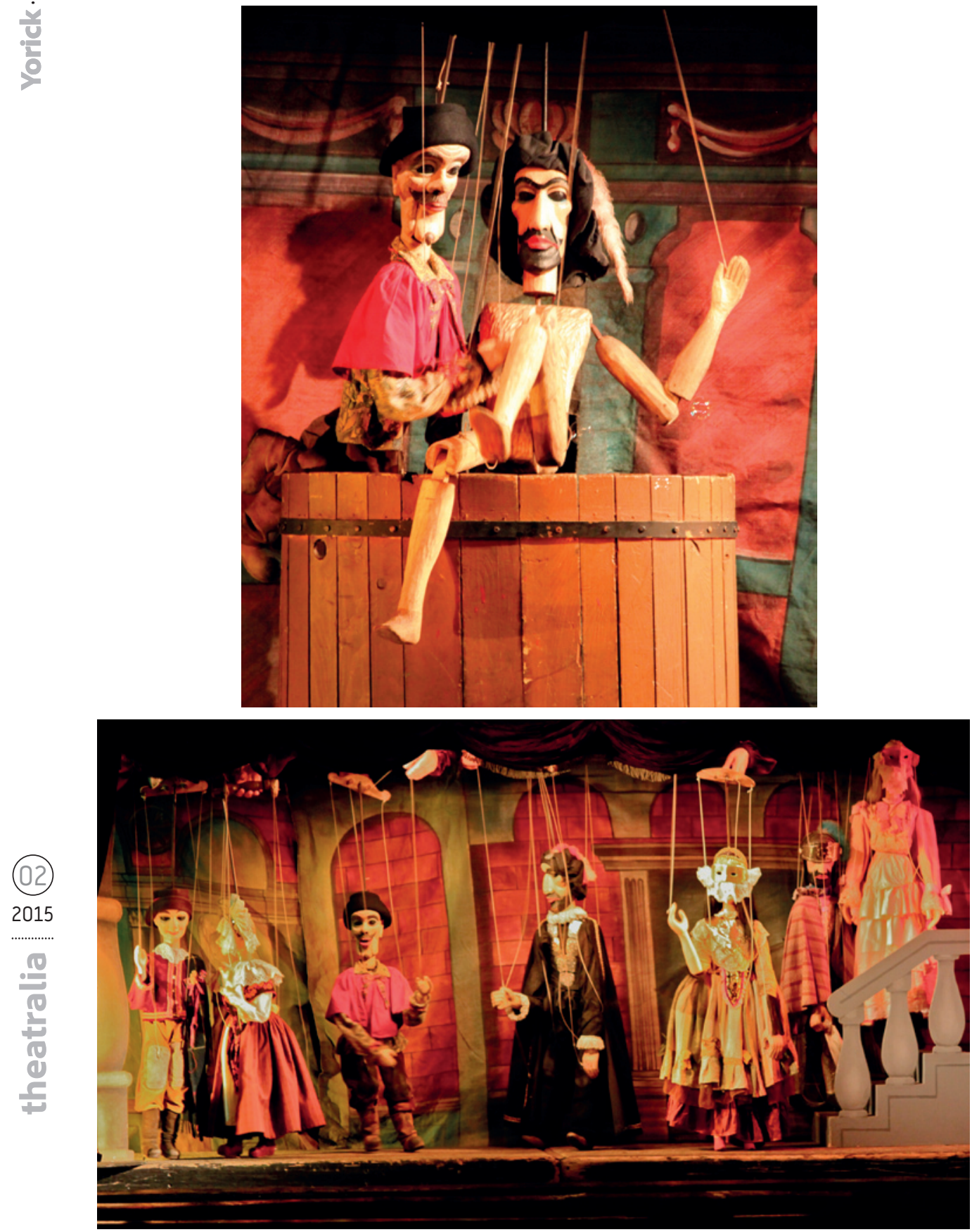

Fig. 10a+b: Karel Brožek’s production of Mozart's Don Giovanni. Scenography by Hana Cigánová. The National Theatre of Marionettes (Národní divadlo marionet), Prague 1991. Photograph @ Josef Ptáček. 


\section{Turning to Tradition as an Act of Rebellion - Existentialist Puppets}

Certain stagnation in our professional theatres during the 1970s and 1980s (with the exception of DRAK Theatre in Hradec Králové), when only a handful of our puppet theatres surpassed the average standard; ${ }^{6}$ was, after 1990 , replaced by a peculiar situation that one might consider (at least within the framework of the search for roots and identity of the society of the time) an open acknowledgement of tradition. It was chiefly the productions Loos's late 1770s Czech Opera about a Chimney (Opera česká o komínku), staged under the title The Baroque Opera (Barokni opera, 1992) at the Forman Brothers' Theatre, the now legendary Don Giovanni (1991) at the National Marionette Theatre in Prague, and The Headless Knight (Bezhlavý rytír, 1993) by Iva Peřinová at The Naïve Theatre in Liberec that shifted audiences' attention to the new approach to this kind of theatre.

Illusionist productions on classic proscenium arch stages with marionettes were, in the cases of the Baroque Opera and Don Giovanni, enriched with intermezzos that included live-actor playing (three masked actors in the Baroque Opera), or with another kind of puppet (in Don Giovanni, it was, for instance, a wayang puppet of Mozart in the proscenium) and this inspiration by tradition, as well as artistic distance from it, accompanied by comic exaggeration (a typical feature of Czech puppet theatre), met with great acclaim for these plays, both from indigenous Czech and foreign audiences.

In spite of the general enthusiasm over these productions, however, they only signalled a need for the commencement of a new form of puppet theatre - under new social and cultural conditions. Accordingly, the situation for puppet theatre was paradoxically not very convenient. Its metaphorical quality, which, with its possible allegories, attracted adult audiences alike during the 1970s and 1980s, was suddenly over and the theatres had to return to predominantly child-targeted audiences and adapt their repertoires accordingly. Besides the statutory theatres, several independent companies fought for a share of the market; however, only a very few of these attracted audiences' attention and have kept it since - for example, the Cake and Puppet theatre (Buchty a loutky), which, by means of its unworldly approach to tradition, its work with objects and its employment of other than canonical dramatic texts, has created its own peculiar style. Continuo Theatre, which started on an amateur basis with simple forms of puppet theatre, has also established itself; this it has done through a combination of puppet, movement and visual art theatre with a specific philosophy: the company draw on a return to pre-theatricality, to myths and to site specific forms of performance. Following a brief episode in the town of Cheb, Líšeň Theatre was definitively constituted in Brno and is

6 Companies with an acceptably high standard might be considered as follows: The Controlled Theatre (Vedené divadlo), which was founded in 1968 by Karel Makonj and dissolved by a cunning administrative decision in 1972 (DUBSKÁ 2000: 508; DVOŘÁK 2007), the puppet conquests by the Klepl Family Theatre, Forman and Herodes and the Váňa Family, with which, during the Theatre Fair of 1985 and 1986, both Forman brothers played (PANTÁKOVÁ 2011: 66-70), and several outstanding amateur puppet companies (such as the 'C' Theatre Company of Svitavy, lead by Karel Šefrna, or The Paraple (Umbrella) Company with Luděk Richter. 
one of the very few theatres that reflect upon current social topics (including political and ethical issues, and questions of and ethnicity). This not-very-rich stock is completed by the Theatre of the Forman Brothers (founded more than two decades ago), which draws on the heritage of both the puppet and the funfair tradition. These forms the theatre innovatively develops, achieving great success with audiences. Some of the then progressive groups later on merged with the crowd of independent companies, whose directions - apart from a very few exceptions - filled the blank spaces in production for the youngest children.

\section{Generational Changes in Relationship to Tradition}

It is no surprise that puppet theatre as I have just presented it, namely theatre that was losing its social prestige, started evading the interest of young theatre practitioners, chiefly those who were supposed to develop and cultivate this art; because it is a commonplace that it is mainly the younger generation that considers tradition to be obsolete. The situation of traditional forms of puppet theatre is not much better; and as far as contents are concerned, nobody thinks about them in what seem to be more superficial times. The situation at the Department of Alternative and Puppet Theatre (DAMU) only mirrors this general lack of specific interest in puppet theatre as such.

The particular nature of puppet theatre is often discussed and explanations are searched for that would hardly seem valid to a laymen, not to mention an expert. The term 'puppet theatre' as if had dissolved into the term 'alternative' - as if puppetry were just one form of alternative theatre, and not vice versa: that puppetry itself contains a number of alternatives (LEŠKOVÁ DOLENSKÁ 2011).

In the course of the next twenty years, the great return to the tradition of Czech puppet theatre (chiefly the echo of the late nineteenth- and early twentieth-century tradition of marionettes) changed into reconsideration and, ultimately, rejection. The question is: Why? It seems as if Czech puppetry had eaten its fill of the previously denied opportunity to admit its old tradition in the creative replicas mentioned above and that, ultimately, professionals lost interest in it. The theatre of figures was replaced by the theatre of objects, by the incorporation of live-actors' dramatic techniques, and some of the techniques of alternative theatre (i.e. physical and dance theatre, and the new circus). Talks, initially inconspicuous but later on clearer, about the end of Czech puppet theatre as such appeared; but what did they mean? The loss of skill? The disappearing of work that involved the figurative, illusionary appearance of puppets? The debates went as far as 'counting the number of puppets on stage' - which was a, question that often worried the juries at Skupa's Pilsen Festival because they refused to acquiesce to live-acting techniques on puppet stages and, according to the then applicable rules of the festival, they used to disqualify productions with not-enough puppets uncompromisingly. 


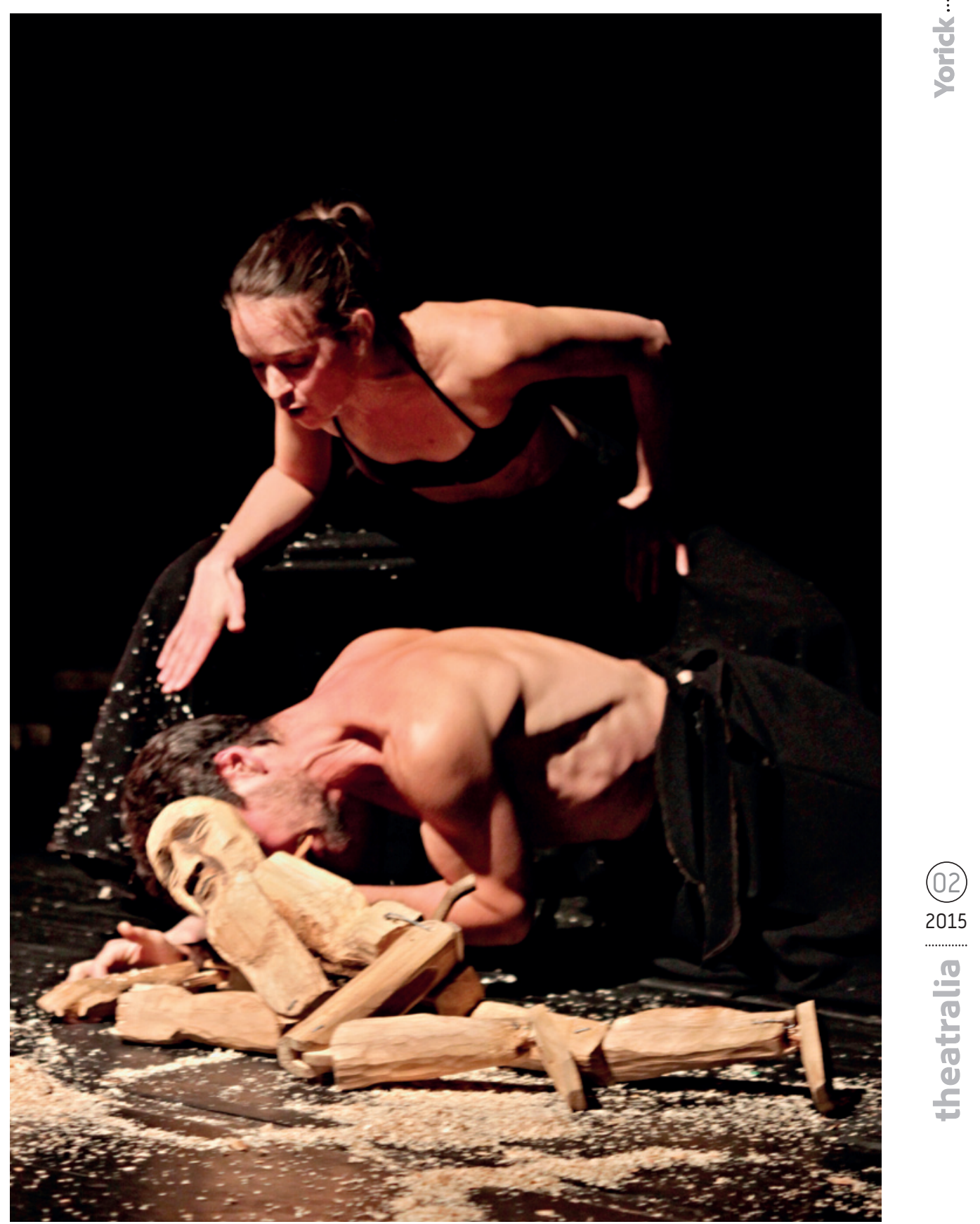

Fig. 11: Pavel Štouračs production of Den osmý (The Eighth Day). Scenography by Helena Štouračová. Divadlo Continuo Theatre, 2014. Photograph @ Michal Drtina. 


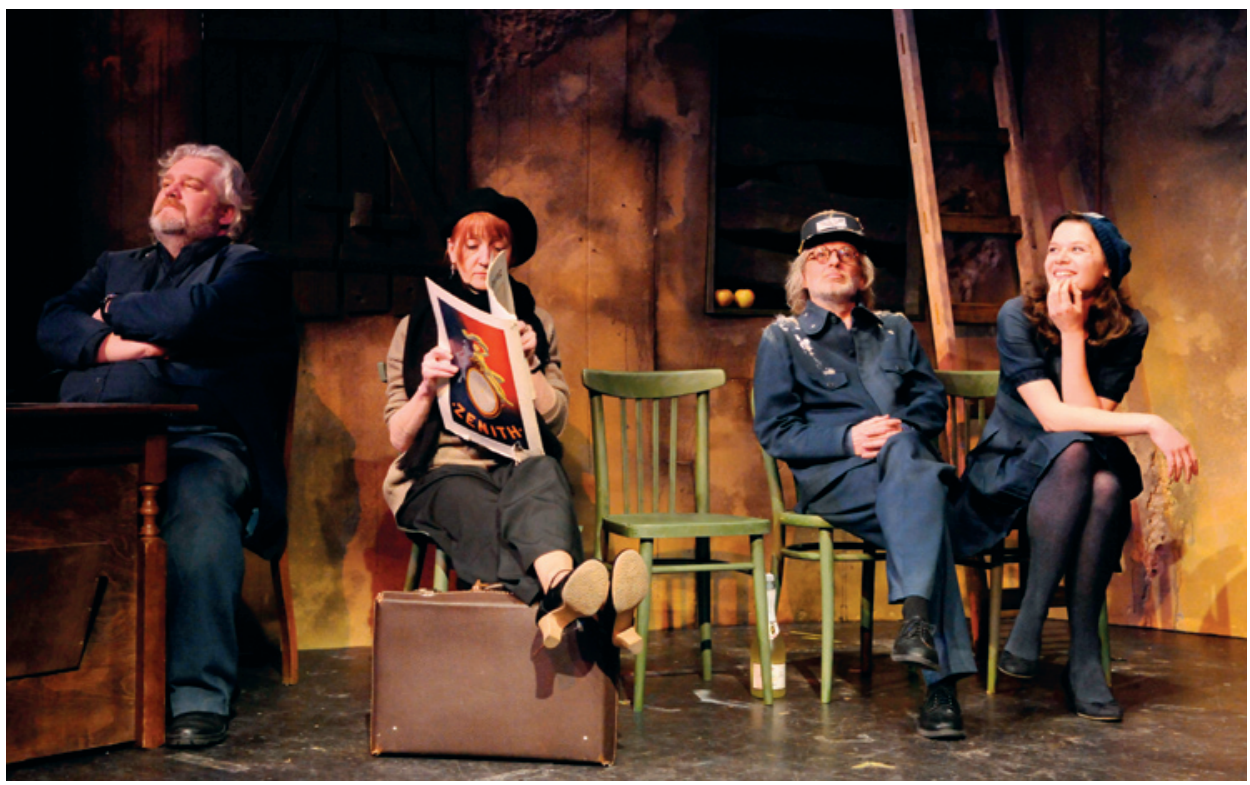

Fig. 12: Jakub Vašíček's production of Bohumil Hrabal, Tomáš Jarkovský and Jakub Vašíček's

Closely Observed Trains (Ostře sledované vlaky). Scenography by Ivan Nesveda. Divadlo Alfa, Pilsen 2014. Photograph (C) Jan Rauner.

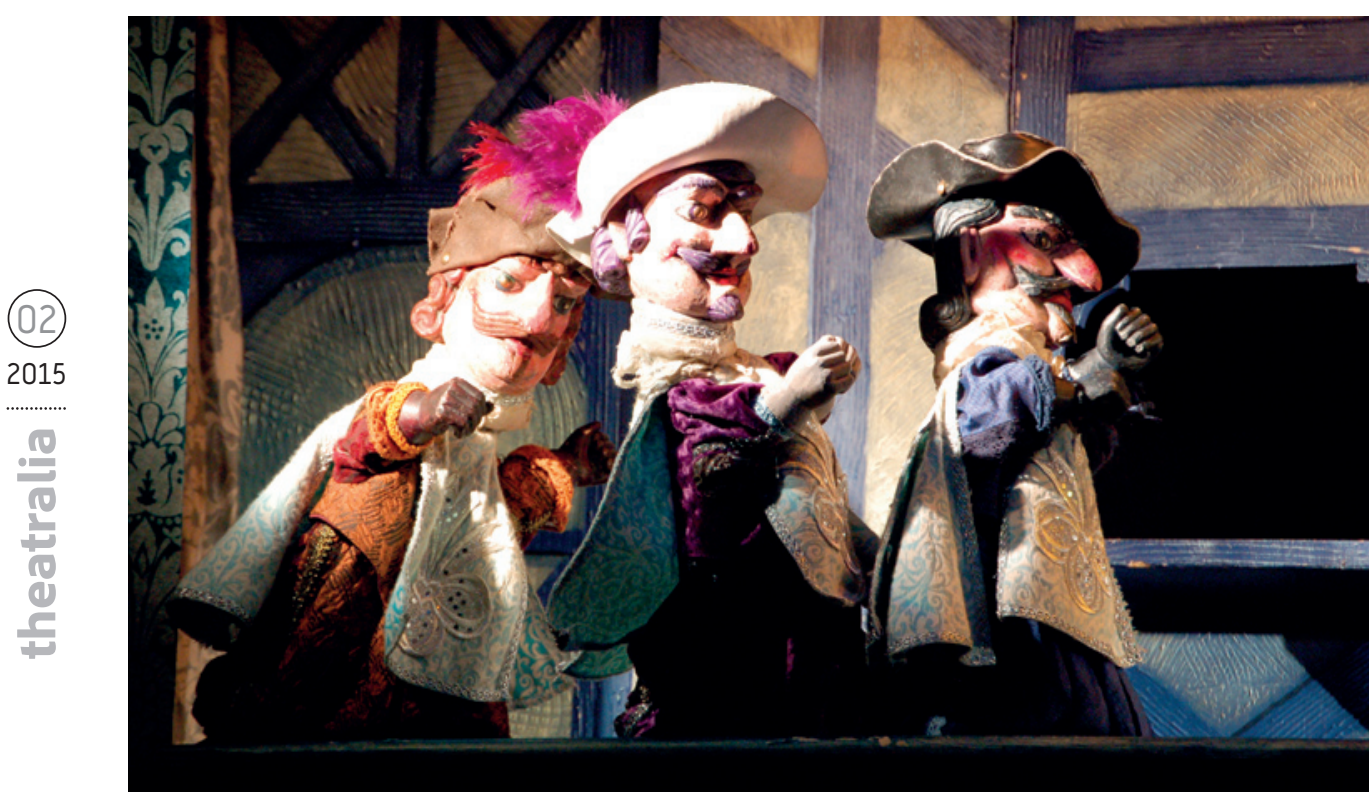

Fig. 13: Tomáš Dvořák’s production of Tomáš Dvořák, Ivan Nesveda and Pavel Vašíček’s The Three Musketeers (Tři mušketýři). Scenography by Ivan Nesveda. The Alfa Theatre, Pilsen, 2006. Photograph (c) Kateřina Lešková Dolenská. 
A number of issues are visible chiefly in dramaturgy: the lack of new texts for this theatre form, and, consequently, the lack of training and development in direction and playing with puppets. We can demonstrate this in several examples from the repertoires of our statutory theatres, for which we can talk about 'puppet theatre' only with a great hyperbole (with all due tolerance to the breadth of term that can now contain both the notion of puppet-ness and of puppet-like-ness). We could in this regard mainly mention recent productions of The Minor Theatre in Prague, such as How Roosters Painted the World (Jak kohouti obarvili svět, 2014); however, we can also observe this trend even in those theatres that have been the traditional 'strongholds' of Czech puppetry - for instance, DRAK theatre (a case in point is their production Icarus (Ikaros, 2013); the Naïve Theatre in Liberec Babu and the Parrot (Babu a papoušek, 2012); The Magical House (Kouzelný dìm, 2013); or Alfa Theatre in Pilsen (Hamleteen, 2012, and Closely Watched Trains (Ostře sledované vlaky, 2014). With the independent companies that started out with puppet theatre, the situation is no different. The sad state of things was shown by one member of the jury at Skupa's Pilsen Festival 2014, Vladimír Hulec, who observed:

I had the impression that, in the past, puppets were mainly copying the world; then [for a while] they themselves were creating it; and now, it is as if they were stepping back before the actor and theatre as such. What is puppet theatre anyway? Is it defined by the puppet, mask, costume, set design, object(s) on the scene, or is it a kind of, let us say, approach to the theatre and to theatre form? I do not intend to answer these questions in my text, nor do I believe they are easily answerable [...] Technically, the biggest change took place in the subtitle of the festival, when, in 2010, the word 'alternative' was added to the word 'puppet'. Even two years ago [HULEC 2012], I contemplated in The Puppeteer (Loutkár) magazine what the added word signifies and who should attend the Skupa festival. It is clear that the subtitle copies the post[Velvet] Revolution name of the Puppet Department of the Theatre Faculty of the Academy of Performing Arts in Prague, which decided to go down this path (that is, a puppet + alternative one). But the characteristics of 'alternative' are much broader than the organisers can yet imagine. However, it is a good thing that they respect certain boundaries in relation to what the general notions are of what constitutes puppet theatre, who is a puppeteer, and what and who is, strictly speaking, an alternative to that. If they did not do this, the festival would transform into something totally different and would forever lose its unique flavour. It will always be necessary to ask the question 'who is suitable for the festival?'; it will also be necessary to make the boundaries penetrable and to argue about, and discuss, who, why, how often and how much should be at the festival. (HULEC 2014: 22-7) 
Czech Puppet Theatre - Tradition, Legend, and Reality: or, is Contemporary Czech Puppet Theatre ...

The low-level of appeal for the genre in domestic production ${ }^{7}$ naturally brings about the disappointment of the young generation of practitioners, who do not see in puppet theatre any future for their artistic career. It is true that their scepticism originates, in many cases, from ignorance - because when they are introduced to outstanding achievements of domestic or world puppet production (from Jan Švankmajer, through Josef Krofta, to Philippe Genty, Eduardo de Paiva Souza or Neville Tranter), the result is usually surprise and admiration on their part.

Set designer, pedagogue and the head of the Unit of Stage Design of the Department of Alternative and Puppet Theatre, Faculty of Theatre, Academy of Performing Arts in Prague, Robert Smolík, described this issue in his contribution to the discussion at the aforementioned seminar in Hradec Králové:

I hold the opinion that the crucial problem of contemporary puppet theatre is cowardice. The cowardice to risk and try new things. I can see how Czech puppet theatre keeps on repeating the same safe patterns, varying them ad infinitum, assuring itself of how good it is, without, however, having produced in the past more than ten years anything that would be comparable to the best in Czech [actors'] theatre, not to mention theatre abroad. Of course, there are decent productions for children; and I am aware of the fact that plays for children are the main production of puppet theatres; for the healthy existence of the form, however, there seems to be an ambitious project missing that would, through puppets, speak to an ordinary adult audience in contemporary theatre language.

If I ask my students whether they have seen a puppet theatre play that they have enjoyed, they look at me puzzled, shaking their heads, indicating that no, there is no such a thing. It is clear that theatre for children does not interest them, them at their stuck-up age of twenty-five. A few amongst the older of them might say that they liked Piškanderdulá. Yes, twenty years ago, seeing this production was even for me one of those experiences that made me want to work with puppets.

Puppet theatre has shut itself off from the wider world; it can live it its self-pity by itself. (SMOLÍK 2014: 17)

What might be both disturbing and mobilising at the same time is the fact that we have started to treat puppet theatre as if it were an endangered species. In acknowledging this,

7 I am outlinibng a general trend here. There are, of course, exceptions to any general rule, such as several adored productions that have recently brought their authors significant success with both domestic and foreign audiences. These are chiefly: The Three Musketeers (Tři mušketýríi) of Pilsen's Alfa Theatre, directed by Tomáš Dvořak, who also stood behind the success of The Headless Knight in the early 1990s and, later, Ali Baba and the Forty Thieves (Alibaba a čtyřicet loupežníků); The Last Trick of Georges Méliès (Poslední trik Georgese Mélièse) by DRAK theatre, directed by Jiří Havelka; and also the more-intimate work of Hana Vořrišková and Tomáš Hájek, who, collaborating together on several productions at the Líšen Theatre in Brno, such as Sávitrí or Blood Hygiene (Hygiena krve), have resurrected the techniques of paper, or shadow theatre (which has historically been less common in the Czech Republic); and lastly, the work that the Slovenian puppeteer Matij Solce has created on the Czech scene, or with students from the Department of Alternative and Puppet Theatre at DAMU in Prague. 
let us realise that every time we want to save a rare species of bird or plant, a number of studies appear, testifying to the species' existence, or voices warning against its extinguishment. Recently, a number of publications have appeared charting chiefly the history of puppet theatre and its traditional forms, including synoptic encyclopaedias and various informative handbooks. Regional European Puppet Museums have intensified their research activities, focused on traditional forms, and typical of the geographical area in question. Documentaries about the 'masters' of the artform are being made; and indicative of a slow demise is also the fact that various forms of puppet theatre have entered the UNESCOS's lists of cultural heritage.

The problems relating to how we struggle with the present situation start even with terminology. In the late 1980s, we used to call the form of theatre that operated somewhere around the border between puppet theatre and live actors' theatre 'theatre of the third kind' - a term coined then by Henryk Jurkowski - or the 'theatre of actors and puppets' in Makonj's view of the problem (DVOŘÁK 2007). Later, we were forced to enrich our non-traditional forms of theatre (that is, forms of puppet performance with the operator uncovered) under the banner of the fashionable term the 'theatre of objects' (which category can include various ideas about puppet theatre); the new term 'figural theatre' entered the terminology, existing alongside 'puppet theatre' (or the German 'Marionettentheater'); more recently, another concurrent term 'the theatre of materials' has appeared. Such terminological ambiguity gives the impression that the label 'puppet theatre' is something pejorative, even inferior - a form that is distant from, or insufficient to, modern theatrical expressions and ambitions. But it is perfectly possible that, in current expressions of puppet theatre, we are encountering something yet intangible, for which we do not have a name - a name that we will search for perhaps not only amongst puppet theoreticians:

Current puppet theatre and derived theatre forms can attract the attention of renowned researchers, who, in accordance with their experience, can apply methods of philosophy, psychology or even anthropology to an analysis and interpretation of the artistic expression of puppets. (JURKOWSKI 2015: 16)

And that is just terminology we are discussing! Let us also recall how many attempts at defining the puppet have appeared lately, confirming that the simplest definitions tend to be the most apposite ones. Any effort to cover comprehensibly the whole philosophical and technological diversity of this form of theatre, that has always been oscillating between dramatic and visual art (and changing with historical development and the development of artistic aesthetics), will doom to failure anyone who would attempt a most complex definition. In contemporary puppet theatre - if we still keep this standard terminology - a change in lexicon has taken place, but also a change in dramaturgy. Dramaturgy in the verbal sense, in the sense of narrative, or, to be more precise, in the sense of the creation of new texts, has given way to visual spectacle, experience and 
entertainment (with a few honourable exceptions, chiefly on the part of modern French and even German puppet theatre - which is related to certain rethoricity and pathos in the theatre cultures of these regions). Serious topics have been disappearing - or topics in general - and spectacle is preferred, entertainment in the sense of 'to entertain to death' has become the watchword - which becomes a scourge of our superficial times, that seem to require it.

Changes, therefore, have taken place in the very structure of the foundation stones, that have so far have defined this theatre form. As a further example of the pervasiveness of this trend, let us consider changes in the playing space: from closed to open, with liberated set design, which has loosened with the entrance of the living actor to a space shared with the puppet, as a result of which, an infinite number of possibilities have opened. And I do not even dare to describe, not to mention anticipate, the coming of new technologies and their deployment in the new look puppet theatre. There have been projection technologies and animations working with puppets and objects in virtual reality. One common technique is shooting the action with a camera and its subsequent projection onto the scenography of the stage, which lends the whole production a new visual-dramatic quality. A more and more common technique is also the blending of shadow theatre and computer animation.

Is it possible that contemporary Czech puppet theatre stands with this theatrical 'decomposition, ahead of it as its inevitable development as a theatre form? Is it insufficient motivation that diverts students from this art form in its traditional varieties? Or does their vision of puppet theatre anticipate a new symbiosis of visual and theatrical forms for which we do not yet have a proper name? Is it possible that the crisis in puppet practice signifies the prototypic emergence of a new form of puppet theatre? It is hard to say; even fifteen years ago, the Polish theoretician and historian Henryk Jurkowski noted the problem of the language of contemporary puppet theatre:

Contemporary puppet theatre originates from the will of the theatre artist. The theatre artist, in accordance with his goals, introduces to the scene necessary expressive devices. Sometimes they come from the human world, sometimes from the realm of theatrical objects (puppets), at other times, from the world of everyday objects. Sometimes all of these devices are employed in one work. The theatre artist can be using the puppets continuously (in every work), incidentally (from time to time) or ephemerally (rarely). $\mathrm{He}$ can relate to the conventions of mimetic, epic, literary, or visual theatre. He is a demiurge of his artistic work and its permanent innovator.

This definition does not have a polemical basis. It is a statement of a factual state that - as any factual state - deserves a description and analysis. This is a challenge for future art historians and theatre scholars. (JURKOWSKI 2001: 204) 


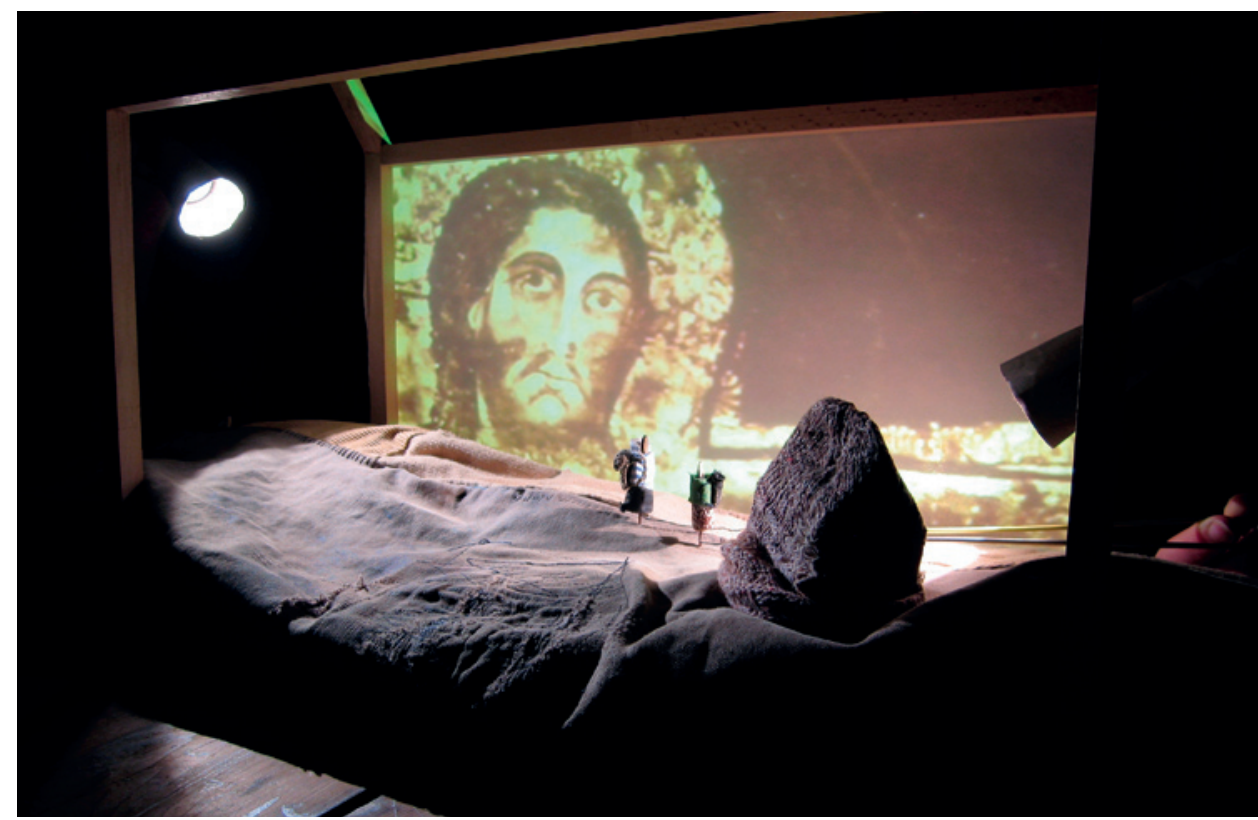

Fig. 14: Veronika Švábová, Jakub Hybler, Tomáš Procházka, Robert Smolík and Jan Dörner's production of Mission. Handa Gote Theatre Company, Prague 2013. Photograph @ Jan Přibylský.

On the other hand, besides all the problems mentioned above, another question offers itself: if we are indeed in such a wretched state, how can we explain the current interest of popular audiences (sadly not of theatre practitioners!) in traditional Czech puppetry and their admiration for its supposed 'golden age'? This interest, both at home and abroad, manifests itself by means of an unprecedented number of publications on the topic, there is interest in the participation of Czech puppet theatres at foreign festivals (and the relatively high number of our puppet festivals does not decline either), there is a rising interest in puppet exhibitions. Is this just a fact that accompanies a fear-for-thefate of 'endangered species'?

The form of contemporary puppet theatre has bewildered us all a bit - we can hardly follow its rapid development and changes in its possibilities. Any predictions of its future development and functions therefore turn against their authors. Nothing is utilitarian. One culture borrows from another; we borrow technologies; we adopt theatre techniques from other theatre forms. But where is the philosophy of the puppet? Where is the properly theorised application of an object that, despite being made of non-living matter, provides valuable testimony about our living, human world? Should it be the puppet-object that, like a mirror, could show us the problems of the world in which we more and more miss living contact? Should it be the puppet that would give testimonies about a different, perhaps better, world? What requirements will it fulfil? Will we redis- 


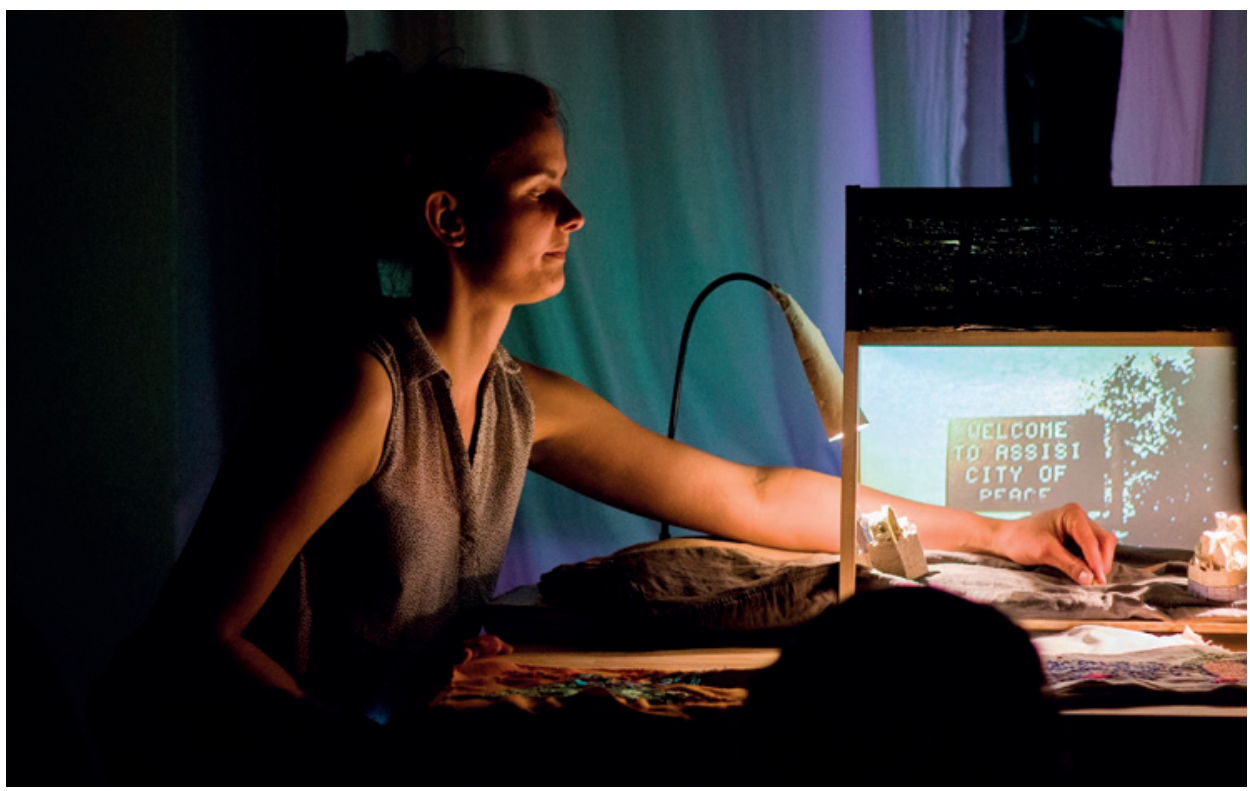

Fig. 15: Veronika Švábová, Jakub Hybler, Tomáš Procházka, Robert Smolík and Jan Dörner’s production of Mission. Handa Gote Theatre Company, Prague 2013. Photograph @ Jan Přibylský.

cover our tactile experiences at workshops, or will we experience warning allegories, conveyed through the stage?

I resigned my employment as an oracle a long time ago; but I am of the opinion that, rather than on the form of puppet theatre itself, we should focus more on its audiences. We are so preoccupied with talking about puppet theatre as a phenomenon that we have forgotten that this phenomenon cannot exist without theatregoers. So who are the current audience members? and what are their needs? Puppet theatre has been trying for almost a century to emancipate from the category of 'just' children's theatre, proving its own maturity by means of a number of avant-garde and bold attempts at theatre expressly for adults. But this kind of audience seems wilfully to reject the name 'puppet theatre' - it is too much connected with childhood for them, with something that contains an immature imaginary, not yet informed and regulated by experience. Such a form is something insufficient for true testimony about the world. That is why the authors opt for a tempting excursions into other spheres and the illusive enchantment of modern technology. But where are the limits of such experiments? And, more importantly, are they not going to be just short-lived toys? Puppet theatre (if we still want to call it that), being in competition with other media, has to offer something different even to child audiences. But what? Just more technical miracles?

Although it is rather fashionable to throw lots of questions to the reader to which the author does not dare to give specific answers, in my own defence, I will say that it is true 
that contemporary puppet theatre keeps on provoking them. Do we lack a theme? Do we lack artisanal and artistic skills, inspired by tradition? What devices do we want puppet theatre to employ when talking about our world?

These are questions that can only be answered by practitioners, for whom this form of theatre will not be just a means for personal exhibition and self-expression, but who will offer their audiences, without artistic egotism, the philosophical explications and theatre-practical devices of the twenty-first century - with sympathetic attunement to audiences' searching, to their needs, and even to their uncertainties.

As far as Czech puppetry is concerned, what is there behind the current call for its salvation? Sentiment? Nostalgia? Or, perhaps fear about a loss of a great export article, which, even nowadays, makes clever use of its laboriously built reputation? It is hard to say; however, what is certain is that today's reality is significantly different from the revered Czech puppet theatre of the second half of the twentieth century.

In the course of the previous century, puppet theatre underwent a crucial change and a shift that saw it develop alongside the society that hosted and created it. It has now to reflect upon the existence of its alternatives. It has to transform in the same manner attempted by opera and ballet (both performance disciplines that, by the way, have recently been using certain elements of puppet theatre as well).

The return to puppet theatre cannot be dictated; moreover, the question remains: what kind of puppet theatre we are talking about anyway? Is the puppet, as we have understood it up to now, capable of expressing current events? And again: are we really sure what we want? Moreover, are we indeed certain that we do not mistake calling for 'revival' or 'preservation' of puppet tradition as calling for the return of the classic puppet? These two things are totally different.

If we look into history, we realise that revolts in Czech puppet theatre took place at the level of direction and dramaturgy; as a result of these elements defining themselves in contrast with tradition. Recently, we have been lacking in terms of decent dramaturgy for this new theatre; another problem is that there has been no revival in terms of the devices (the last fad was, in this sense, Black Light Theatre and, subsequently, an invasion of 'mannequins'). Moreover, the acting work itself is weakened, whether we take it the level of mere skill (who can nowadays properly control a marionette, or a puppet controlled from below? - most puppet controllers work with a standing puppet or toy: a mannequin), or at the level of the relationship between the manipulator and the object as an acting partner, or subject. The scenography of puppet theatre - using new technologies - is in a better situation: computer compositions, projectors, shooting action on the stage and augmenting it on screen follow the development of modern set devices very flexibly; but, as history has shown several times, extravagant spectacle has never been to able to save the day just by itself. What is missing is a really contemporary theme, a reflection upon contemporary life - not its distant metaphor by means of historical retrospect, from which an audience is supposed to compose their own image(s) by themselves. 
Czech Puppet Theatre - Tradition, Legend, and Reality: or, is Contemporary Czech Puppet Theatre ...

Thus we return to the very beginning - let us watch closely the development of contemporary puppet theatre, to ascertain whether it contains more alternatives, or whether it returns to tradition; and let us not try enforce what any of us might individually or collectively think is its only true and orthodox form. Let us be sensitive watchers of the change in theatre production with respect to the complex theatre production environments and machineries in Europe and other regions, and, most of all, let us be more sensitive to the audience, without whom this form of art could not exist. Let us try to rediscover for 'our' audience, over and over again, principles, possibilities and rudiments of puppet theatre without a raised patronising finger or sighs over any spectator's ignorance, or lack of taste.

We cannot find the answers to the questions that I have raised here immediately: after all, Czech puppetry has been searching for such solutions for more than a hundred years.

\section{Bibliography}

BEZDĚK, Zdeněk. 1969. Kontinuita a diskontinuita [Continuity and Discontinuity]. Československý loutkár [The Czechoslovak Puppeteer] (1969): 5: 81-8.

BEZDĚK, Zdeněk. 1983. Dějiny české loutkové hry do roku 1945 [A History of Czech Puppet Theatre up to 1945]. Praha: Divadelní ústav, 1983.

ČESAL, Miroslav. 1983. Živý herec na loutkovém divadle [The Live Actor in the Puppet Theatre]. Praha: ÚKVČ, 1983.

ČESAL, Miroslav. 1987. Kapitoly z historie českého loutkového divadla II [Chapters of a History of Czech Puppet Theatre II]. Praha: SPN, 1987.

ČESAL, Miroslav. 1991. Úvahy o loutkářské dramaturgii [Reflections on Puppet Dramaturgy]. Praha: SPN, 1991.

ČESAL, Miroslav. 1995. Kontinuita a diskontinuita II [Continuity and Discontinuity II]. Loutkář [The Puppeteer] (1995): 12: 270-3.

ČESAL, Miroslav. 1996. Kontinuita a diskontinuita II [Continuity and Discontinuity II]. Loutkář [The Puppeteer] (1996): 1: 4-6; 2: 31-3.

CÍSǍ̌, Jan. 1978. Na křižovatce aneb Po Plzni 1977 - K postavení loutkového divadla ve společnosti [At a Crossroads, or After Pilsen 1977: On the Position of Puppet Theatre in Society]. 12 parts. Československý loutkáŕ [The Czechoslovak Puppeteer] (1978): 1: 7; 2: 33; 3: 56; 4: 78; 5: 104; 6: 127; 7: 148; 8-9: 181; 10: 231; 11: 250; 12: 272.

CÍSǍ̆, Jan. 1985. Teorie herectví loutkového divadla [Theory of Puppet Theatre Acting]. Praha: SPN, 1985.

DRÁBEK, Pavel. 2009. Anglické hry u našich loutkářů a naopak [English Plays and Czech Marionettists]. Divadelné revue [Theatre Review] (2009): 3: 27-44. A reworked English language version published as: 'English Comedy and Central European Marionette Theatre'. In Robert Henke and Eric Nicholson (eds.). Transnational Mobilities in Early Modern Theater. Farnham: Ashgate, 2014: 177-96. 
DUBSKÁ, Alice. 2000. Vedené divadlo (heslo) [The Led Theatre Company (an entry)]. In Eva Šormová (ed.): Česká divadla - encyklopedie divadelních souborů [Czech Theatres - Encyclopedia of Theatre Ensembles]. Praha: Divadelní ústav, 2000: 508.

DUBSKÁ, Alice. 2000. Tradice je vědomím souvislostí [Tradition is an Awareness of Continuities]. Loutkár [The Puppeteer] (2000): 1: 13.

DUBSKÁ, Alice. 2004. Dvě století českého loutkářství [Two Centuries of Czech Puppet Theatre]. Praha: AMU, 2004.

DUBSKÁ, Alice, Nina MALÍKOVÁ, Jan NOVÁK and Marie ZDEŇKOVÁ. 2006. Czech Puppet Theatre Yesterday and Today. Praha: Divadelní ústav, 2006: 26-7, 34-8, 42-4, 50-9, 62-7.

DVOǨÁK, Jan and Věra ELIÁŠKOVÁ et al. 2007. Karel Makonj a Vedené divadlo. [Karel Makonj and the Management of Theater]. Praha: Pražská scéna, 2007.

ETLÍK, Jaroslav. 1999. Divadlo jako zakoušení [Theatre as Experiencing]. Divadelní revue [Thetre Review] (1999): 1: 3-30.

HULEC, Vladimír. 2012. České loutkové divadlo na dějinné křižovatce [Czech Puppet Theatre at a Historical Crossroads]. Loutkár [The Puppeteer] (2012): 4: 164-7.

HULEC, Vladimír. 2014. Ve znamení recyklací [Under the sign of Recycling]. Loutkár [The Puppeteer] (2014): 4: 22-7.

JURKOWSKI, Henryk. 1957. Magie loutky [The Magic of the Puppet]. Transl. by Jana Pilátová. Praha: Nakladatelství Studia Ypsilon, 1957.

JURKOWSKI, Henryk. 2001. Konec specifik? [The End of Specifics?] Loutkár [The Puppeteer] (2001): 5: 202-4. Transl. from Polish by Jana Pilátová.

JURKOWSKI, Henryk. 2004. Metamorfózy bábkového divadla v 20. storočí [The Metamorphoses of the Puppet Theatre in the $20^{\text {th }}$ Century]. Transl. by Renata Majerčíková and Ida Hledíková. Bratislava: Divadelný ústav, 2004.

JURKOWSKI, Henryk. 2015. Překračování hranic vlastního druhu [Crossing the Boundaries of our own Species]. Loutkář [The Puppeteer] (2015): 2: 16-9. Transl. from English by Daniel Dolenský.

KRÁTKÝ, Radovan. 1962. O mladých, starších a starých loutkárích [On the Young, Older and the Oldest Puppeteers]. Divadelní noviny [Theatre News] 1962: 5 (15. 5. 1962): 21-2.

KYSELOVÁ, Eva. 2013. KALD - variácie na klasiku [KALD: DAMU's Department of Alternative and Puppet Theatre - A Variation on the Classics]. Loutkár [The Puppeteer] (2013): 3: 18-20.

LAMKOVÁ, Hana. 2009. Černá hodinka 5 [The Blackout Hour 5]. Loutkáŕ [The Puppeteer] 2009: 1: 12-7.

LAMKOVÁ, Hana. 2009. Černá hodinka 6 [The Blackout Hour 6]. Loutkár̆ [The Puppeteer] 2009: 6: $62-3$.

LEŠKOVÁ DOLENSKÁ, Kateřina. 2011. Loutkáři bez loutek? [Puppeteers without Puppets?]. Loutkár [The Puppeteer] (2011): 2: 75.

LEŠKOVÁ DOLENSKÁ, Kateřina. 2014. České profesionální loutkové divadlo dnes [Czech Professional Puppet Theatre Today]. Loutkár̆ [The Puppeteer] (2014): 1: 11-3.

MAKONJ, Karel. 2014. O křehkosti spájení [On the Fragility of Bonding]. Loutkár [The Puppeteer] (2014): 4: 20-1. 
Czech Puppet Theatre - Tradition, Legend, and Reality: or, is Contemporary Czech Puppet Theatre ...

MALÍK, Jan.1969. Matěj Kopecký - legenda a skutečnost [Matěj Kopecký: the Legend and the Reality]. Praha: Státní pedagogické nakladatelství, 1969.

MALÍKOVÁ, Nina. 2011. Loutkářské Mirotice [The Puppeteers' Mirotice]. Loutkář [The Puppeteer] (2011): 4: 169.

MALÍKOVÁ, Nina. 2012. Moderní české loutkářství a jeho ohlasy v Muzeu loutkářských kultur [Modern Czech Puppetry and the Responses in the Chrudim Puppetry Museum]. In Obrazy z dějin českého loutkářství. Praha/Chrudim: Arbor vita/Muzeum loutkářských kultur, 2012: 126-45.

MALÍKOVÁ, Nina and Petr PAVLOVSKÝ. 2013. Společenská emancipace evropského loutkářství a jeho česká specifika [The Social Emancipation of European Puppetry and its Czech Specifics]. In Živé dědictví loutkářství [The Living Legacy of Puppetry]. Praha/Chrudim: Arbor vita/ Muzeum loutkářských kultur, 2013: 40-6.

MALÍKOVÁ, Nina. 2013. Modern Czech Puppets. In Strings Attached - The Living Tradition of Czech Puppets. Ohio: Columbus Museum of Arts, 2013: 40-65.

NOVOTNÝ, Josef Alois. 1958. Bukurešt - Praha - Chrudim přesedat [Bucharest - Prague - Chrudim: All change!]. Československý loutkáŕ [The Czechoslovak Puppeteer] (1958): 11: 242-5.

OBRAZCOV, Sergej Vladimirovič. 1947. Herec s loutkou [An Actor with a Puppet]. Transl. by Jan Malík. Praha: Československý kompas, 1947.

OBRAZCOV, Sergej Vladimirovič. 1955. Moje povolání [My Profession]. Transl. by Jan Malík and Emil Havlík. Praha: Orbis, 1955.

POSNER, Dassia. N., Cladia ORENSTEIN and John BELL. 2014. The Routledge Companion to Puppetry and Material Performance. London/New York: Routledge, 2014.

RICHTER, Luděk. 2000. Tradice a současnost [Tradition and the Present]. Loutkář [The Puppeteer] (2000): 3: 105-7.

RICHTER, Luděk. 2013. Přelet nad Přeletem [Flying over the Flying Festival]. Loutkár [The Puppeteer] (2013): 6: 31-5.

SMOLÍK, Robert. 2014. Zbabělost riskovat a zkoušet [Cowardice Take Risks and Try Things Out]. Loutkár [The Puppeteer] (2014): 4: 17.

VAŠÍČEK, Pavel. 2014a. Loutkářská katedra DAMU - prvních 20 let (1952-1972), II. etapa (19561962), část 8 [The Puppetry Department of DAMU: the First 20 Years (1952-1972), the $2^{\text {nd }}$ phase (1956-1962), part 8]. Loutkár [The Puppeteer] (2014): 4: 5-9.

VAŠÍČEK, Pavel. 2014b. Loutkářská katedra DAMU - 20 let (1952-1972), II. etapa (1956-1962), část 9 [The Puppetry Department of DAMU: the First 20 Years (1952-1972), the $2^{\text {nd }}$ phase (1956-1962), part 9]. Loutkár [The Puppeteer] (2014): 5: 7-10.

VAŠÍČEK, Pavel. 2014c. Loutkářská katedra DAMU - 20 let (1952-1972), II. etapa (1956-1962), část 10 [The Puppetry Department of DAMU: the First 20 Years (1952-1972), the $2^{\text {nd }}$ phase (1956-1962), part 10]. Loutkár [The Puppeteer] (2014): 6: 9-11.

VITVAR, Jan. H. 2012. Kašpárek v kómatu [Kašpárek in a Coma]. Respekt.cz (2012): 7: 59-61.

VOJTÍŠKOVÁ, Zuzana (ed.). 2013. Živé dědictví loutkářství [The Live Legacy of Puppets]. Praha: Akademie múzických umění, 2013. 


\title{
Summary
}

This article reflects on the current state of Czech puppet theatre, discussing the position of puppet theatre in contemporary Czech society, set against a background of what is an often-overwhelming cultural heritage. The essay uses historical inquiry and rhetorical interrogation to set out before readers some of the thorny problems that need to be solved before a foundation can be established on which the future of Czech puppetry can be based.

\section{Keywords}

Czech puppet theatre, Czech cultural heritage, traditional Czech theatre, theatre dramaturgy

\author{
Translated by Filip Krajník
}

DOI: $10.5817 /$ TY2015-2-10

\begin{abstract}
Nina Malíková (nina.malikova@divadlo.cz) is a theatre critic, historian, journalist and translator. She graduated from the Department of Theatre History and Theory at Charles University, Prague. She worked as a dramaturg at the Divadlo Vitězného února Theatre (now called Klicpera Theatre) in Hradec Králové, in the S. K. Neumann Theatre (now called Palmovka Theatre), in the Lampion Puppet Theatre in Kladno, and later as a researcher in the Theatre Institute. Since 2000, she has been the editor-in-chief of the Loutkár (The Puppeteer) magazine, and has taught at the Department of Alternative and Puppet Theatre at DAMU (Theatre Faculty of the Academy of Performing Arts, Prague). She has also curated a number of puppetry exhibitions in the Czech Republic and abroad. Currently, she is an expert consultant on Czech puppet theatre at the Arts and Theatre Institute in Prague (CZ).
\end{abstract}


